\title{
LORETA VAIČIULYTĖ-SEMĖNIENĖ
}

Lietuvių kalbos institutas

\section{DIDELIS DE்KUI IR DE்KUI LABAI \\ DABARTINĖJE LIETUVIŲ (RAŠTO) KALBOJE}

ESMINIAI ŽODŽIAI: padėkos konstrukcija, jaustukas, inversija, aktualioji sakinio skaida, tarpkalbinè komunikacija.

\section{ANOTACIJA}

Šio straipsnio objektas - padèkos konstrukcijos dèkui, ačiū labai ir didelis dèkui, ačiū. Tikslas - remiantis Dabartinès lietuvių kalbos tekstyno (DLKT) medžiaga, išsiaiškinti kalbamųiu padèkos raiškų santykị su labai dèkui (ačiū), labai dèkoju, esu labai dèkingas, didelè padèka ir dèkoju labai, labai esu dèkingas ar pan.; kitų kalbų žodžių tvarkos ịtaką inversinėms padèkos raiškoms lietuvių kalboje. Padèkos konstrukcijos nag rinëjamos sintaksiniu-semantiniu, aktualiosios sakinio skaidos aspektu. Tyrimas parodè, kad adresantas renkasi inversinę dèkui labai, kai nori pabrèžti pati dèkui arba jo modifikatorių labai, panašiai kaip ir dèkoju labai, dèkingas esu labai atveju. Iš DLKT pavyzdžių paaiškejjo, kad didelis, nuoširdus dèkui linkstama vartoti tais atvejais, kai adresatas dèkui suvokia daiktavardiškai; (in)tranzityviniame sakinyje didelis, nuoširdus dèkui eina predikato argumento pozicijoje pagal didelè, nuoširdi padèka analogiją (Jums tariu nuoširdžia padèka (nuoširdų dèkui), Jums tenka nuoširdi padèka (nuoširdus dèkui)).

\section{IVADAS. TEORINĖS PRIELAIDOS}

Kalbos normos atžvilgiu lietuvių kalbos padèkos konstrukcijos ${ }^{1}$ dèkui (ačiū $)^{2}$ labai ir didelis dèkui $(a c ̌ i u ̄)^{3}$ vertinamos skirtingai. Pavyzdžiui, Antanè Kučinskaitė (1985: 29, dar žr. 1990: 32tt;

1 Padèkos konstrukcijos pagal pragmatikos teoriją - performatyvai, o jie šiame straipsnyje, remiantis Egidijaus Zaikausko požiūriu (2002), suprantami plačiąja prasme.

Plačiau apie performatyvumą kaip sintetinį reiškinị, turintį gramatinių, leksinių-semantinių bei pragmatinių požymių, žr. Zaikauskas 2000, 2002 ir ten cituojamą literatūrą.

${ }^{2} \mathrm{Plg}$. DLKŽ ${ }_{\mathrm{e}}$ : dèkui - dèkojant sakomas žodis, ačiū; ačiū - mandagumo žodis, sakomas reiškiant padèką, dèkui.

BLKŽ $:$ dèkui - dèkojant sakomas žodis; ačiū - sakoma dèkojant.

${ }^{3}$ Toliau kalbant apie konstrukcijas su labai dèkui, dèkui labai, didelis dèkui ar pan. omenyje turimos ir tapačios su ačiū ir atvirkščiai. 
2007: 496) teigia, kad vietoj iš rusų kalbos nekūrybingai išverstų didelis ačiū „lietuviškiau būtų sakyti labai ačiü“. Danguolè Mikulènienè, sudariusi knygelę Kaip nereikia kalbèti (KNK 1991: 9, 26), mano, kad tiek ačiū labai, tiek nuoširdus ačiū yra nevartotini vertiniai, kuriuos derą keisti ị labai ačiū, nuoširdžiai ačiū, dèkui, labai nuoširdžiai dèkoju. Tokios pat nuomonès laikosi ir Jonas Šukys (2003: 293; 2006: 304): iš rusų kalbos nusižiūrètas didelis dèkui turįs būti taisomas ir pirmiausia anglų kalbos pavyzdžiu plintančiuose dèkui labai ,,prieveiksmis labai ị galą nekeltinas“. Padèkos ačiū labai siūloma vengti ${ }^{4}$ Valstybinès lietuvių kalbos komisijos apsvarstytuose ir Ritos Miliūnaitès sudarytuose Kalbos patarimuose (KP2 (S3) 2009: 43). Tapati nuomonè, kuria įprasta remtis ${ }^{5}$, teikiama ir Valstybinès lietuviu kalbos komisijos $\left(\mathrm{VLKK}_{\mathrm{e}}\right)$ konsultacijų banke ${ }^{6}$ : pagal neutralią pažyminio ir pažymimojo žodžio tvarką junginyje (saulèta diena, labai gražus) vengtinus dèkui labai patariama keisti ị labai dèkui ir (ar) labai dèkoju, o konstrukcija didelis dèkui taisytina. VLKK $_{\mathrm{e}}$ konsultaciju banke matyti ir kitokia - profesoriaus Albino Drukteinio nuomonè. Jo manymu, ačiū labai nèra verstinè ir vengtina konstrukcija, nes tai tipiška inversija, kai svarbesnis žodis keliamas į priekį. Taip pat ir Aleksas Girdenis (1996: 302) yra atkreipęs dèmesị, kad daugelio peikiama dèkui labai žemaičiuose esanti nereta ir ausies jiems nerèžia. Tokių ir panašių pavyzdžių yra ir dabartinejje lietuvių rašto kalboje (žr. 1-2 sakinius), kurios pagrindu aiškinamasi jų vartosenos priežastys ir (ne)tinkamumas vartoti.

1) - Gal iš tikro duokit, panèšèsiu kiek. - Ačiū, ačiū širdingai. Sakau, kad mes, laukininkai, ipratę. O tamsta, jaučiu, ne žemès knisëjas. - Iš ko jaučiat? - Iš balso. Iš ko gi daugiau?

2) Atskirai dèkoju Edukologijos katedros vedejai prof. habil. dr. M. B. ${ }^{7}$, nenustojusiai raginti ir drąsinti, rengiant metodinị leidinị. Visiems nuoširdus ačiū. Būsiu dèkinga už pareikštas pastabas ir pasiūlymus.

Monografijoje išsamiai lietuvių kalbos etiketo formulių semantiką ir pragmatiką išnagrinèjusi Giedrè Čepaitienė (2007, dar žr. 2014) inversinès žodžių tvarkos pavyzdžiais ne

\footnotetext{
${ }^{4}$ Vengtinas - ,,rodo, kad vertinamasis reiškinys nėra įteisintas kaip bendrinės kalbos norma, jis vengtinas kaip jau nenorminis ir neturintis perspektyvos arba dar nenorminis, nepakankamai ištirtas ir pan." (KP2 (S3) 2009 : 9).

${ }^{5}$ Žr., pavyzdžiui:

https://www.kretinga.lt/node/10056 (žiūrèta 201810 20);

http://www.santaka.info/?sidx=44556 (žiūrèta 201810 20).

${ }^{6}$ Žr. http://www.vlkk.lt/konsultacijos/98-didelis-aciu-didelis-dekui (žiūrèta 201810 20).

karta.

Dar plg.: http://www.vlkk.lt/naujienos/pakomisiu-naujienos/kp3-sintakse-iii-dalis-apsvarstyta-antra-

„Nutarta nelaikyti klaida pasakymu ačiū labai arba dèkui labai. Žinoma, teiktiniau vra labai ačiū (dèkui), tačiau lietuviu kalbos žodžiu tvarka gana laisva, aplinkybės vartojamos ir prieš, ir po pažyminio, pvz., labai žaviuosi ir žaviuosi labai, labai dèkoju ir dèkoju labai.“”

${ }^{7}$ Kai iliustraciniuose pavyzdžiuose asmenys įvardijami vardu ir pavarde, palikti tik jų inicialai.
} 
kartą remiasi (pvz.: Dékoju joms iš visos širdies $\mathrm{T}^{8}$; Gerbiamoji! Dèkoju širdingai, kad mane apsiimate priglausti Bit 4779 Dèkoju baisiausiai, nežinau, kur be tavęs būčiau dingus GyvK $^{10}$ (Čepaitienè 2007: 184, 187; dar žr. t. p.: 188)), bet dékui labai palieka be komentarų. Šiame straipsnyje remiamasi prielaida, kad tiek dèkoju iš visos širdies / širdingai ar pan., tiek ir 1-ame sakinyje vartojama ačiū širdingai yra motyvuotos konstrukcijos, pasirenkamos vartoti dèl panašiu priežasčių. Einama nuo gramatinių prie pragmatinių kriterijų ir žiūrima, kas turi įtakos renkantis vartoti dèkui labai (ir) ar didelis, nuoširdus dèkui.

Taigi šio straipsnio objektas - padèkos raiškos dèkui labai, didelis dèkui. Tyrimo tikslas - aptarti konstrukcijų dèkui labai, didelis dèkui vartoseną ir jų santyki su labai dèkui; dèkoju labai, labai dèkoju; dèkingas esu, esu dèkingas; didelè padèka ir pan. Keliami uždaviniai: remiantis Dabartinès lietuviu kalbos tekstyno (DLKT ${ }^{11}$ ) medžiaga, išnagrinėti inversinès žodžių tvarkos padèkos raiškas dabartinèje lietuvių rašto kalboje; palyginti jas su neutralios žodžių tvarkos pavyzdžiais; aptarti žodžių tvarkos aptariamose konstrukcijose koreliacijas vertimuose; išsiaiškinti didelis ačiū ir pan. vartosenos priežastis. Tai tekstynu ir vertimais paremtas tyrimas.

Tiriamoji medžiaga - 800 lietuvių kalbos sakinių iš Vytauto Didžiojo universiteto Kompiuterinès lingvistikos centre sudaryto DLKT. Tyrimui rinkti pavyzdžiai su dèkoju, dèkingas, -a, padèka, -q, ačiū, dèkui. İ išplèstinès paieškos laukelị įrašius vieną minètų žodžių paeiliui atrinkti tokie, kur šie žodžiai turi būdvardžiais, prieveiksmiais, prielinksninėmis konstrukcijomis reiškiamų (atributinių, būdo) modifikatorių, pavyzdžiui, didelè padèka, labai dèkingas, iš visos širdies dèkoju, be galo dèkui ir pan. Tyrimui paeiliui atrinkta 120 sakinių, kur performatyvusis veiksmažodis dèkoju turi prepozicinių arba postpozicinių būdo modifikatorių (plg. 3-4 sakinius), 270 sakinių su dèkui, ačiū, 280 - su dèkingas, -a ir 130 sakinių su padèka, -a, kai jie vartojami su prepoziciniais arba postpoziciniais modifikatoriais (plg. 5-9 sakinius, dar žr. $1-2$ sakinius).

3) Brangioji Teta Džordža, be galo dèkoju už žavinga penala.

4) Laikas man yra labai palankus. Dèkoju jums visiems iš visos širdies.

5) - Tai jeigu išbūni metus laiko abonentu, tai nuolaidos, žinai. - Mm... - Suteikia arba minučiu daugiau, ar esamesu, va... - Nu ačiū, labai ačiū!

\footnotetext{
${ }^{8} \mathrm{~T}$ atitinka šiame straipsnyje vartojamą santrumpą DLKT.

${ }^{9}$ Bit - Bitè-Petkevičaitė G. Raštai 6. Vilnius: Vaga, 1968.

${ }^{10}$ GyvK - gyvoji kalba.

${ }^{11}$ Prieiga internete: http://tekstynas.vdu.lt. Didžiąją DLKT dali sudaro publicistika (63,8 proc.), dalis tekstų yra versti iš kitų kalbų. Straipsniui pavyzdžiai iš DLKT rinkti 2018 metų rugsèjo mèn.
} 
6) Buda pasikvietè jị ir tarè: „Čunda, aš savo gyvenime ragavau tik du patiekalus, už kuriuos jaučiuosi nepaprastai dèkingas. Pirma karta tai nutiko Sudžiatoje ir padejo man pasiekti Nušvitima, antra karta - šiuose namuose“.

7) Užtrenkęs duris, jis sugrižo ị savo kabineta. Rodžeris paèmé raktus. - Labai esu dèkingas už tai, ka man pasakète, pone Bitneri. Padèkokite šio komiteto nariams. Bet man... man... man nejauku, kai turiu priimti dovanas.

8) Esu dèkingas pagalbininkams, juvairiu laiku dirbusiems mano padejejjams: p. P. P., V. Š., doc. J. Ž. Nuoširdi padèka „Tèviškès žinių“ ir „Kauno apskrities“ laikraščių darbuotojams, atvèrusiems savo leidinių lapus mano siūlymams ir apmąstymams.

9) Knygos apipavidalinimu rūpinosi dailininkè R. P. ir teksto maketuotoja S. V. Už tai jiems reiškiu nuoširdžia padèkq.

Norint išsiaiškinti, (ar) kokią ịtaką daro kitų kalbų žodžių tvarka padèkos konstrukcijose, straipsnyje remiamasi paieškos funkciją turinčio internetinio vertimų žodyno LINGUEE ${ }^{12}$ medžiaga. LINGUEE pasirinkto žodžio (žodžių junginio) vertimai teikiami pagal pasirinktą kalbų porą, pavyzdžiui, lietuvių-anglų. Čia galima rasti žodžius minimaliame kontekste, lygiagrečiai išverstus įvairiuose tekstuose (Europos Sąjungos institucijų teisiniuose bei politiniuose tekstuose, patentų dokumentuose, bendrovių, organizacijų ir universitetų interneto svetainėse). Pavyzdžių ieškota pasirinkus tokias kalbų vertimo poras: anglų $\rightarrow$ lietuvių, vokiečių $\rightarrow$ lietuvių ir atvirkščiai ${ }^{13}$, ir paieškos laukelyje įrašius, pavyzdžiui, žodžius Dankeschön, padèka, dèkui arba konstrukciją thank you so much, danke schön, labai dèkoju, labai ačiū ir pan. Rasti vertimai su aptariamomis padèkos konstrukcijomis yra iš tokių interneto svetainių: eur-lex.europa.eu, europa.eu, europarl.europa.eu. Toliau remiamasi 128-iomis padèkos raiškomis, kur pagrindinis padèkos konstrukcijos dėmuo abiejose arba vienoje iš vertimo kalbų turi (būdo arba atributinių) modifikatorių. Konkrečiai kalbant, iš 128-ių pavyzdžių 36-i yra tokie, kai tas pats lietuvių kalbos sakinys yra išverstas ir ị anglų, ir ị vokiečių kalbą (t. y. 18 lietuvių $\rightarrow$ anglų ir 18 lietuvių $\rightarrow$ vokiečių) (plg. 10-11 sakinius), 20 - tokių, kai tas pats lietuvių kalbos sakinys susijęs su skirtinga vertimo kryptimi: 10 lietuvių kalbos sakinių išversta iš anglų kalbos (anglų $\rightarrow$ lietuvių) ir tie patys 10 iš lietuvių kalbos išversti ị vokiečių (lietuvių $\rightarrow$ vokiečių) (t. y. anglų $\rightarrow$ lietuvių $\rightarrow$ vokiečių) (plg. 1213 sakinius). Be jų, dar yra 14-a anglų kalbos sakinių, išverstų i lietuvių (anglų $\rightarrow$ lietuvių) ir 10 - atvirkščiai (lietuvių $\rightarrow$ anglų) (plg. 14-15 sakinius); 15-a vokiečių kalbos sakinių, išverstų i lietuvių (vokiečių $\rightarrow$ lietuvių), ir 33 - iš lietuvių i̇ vokiečių kalbą (lietuvių $\rightarrow$ vokiečių) (plg. 16-17

\footnotetext{
12 Prieiga internete https://lt.linguee.com/.

${ }^{13}$ LINGUEE vertimų žodyne nèra lietuvių-rusų ir rusų-lietuvių kalbų vertimų.
} 
sakinius). Taigi turima 15-a vokiečių $\rightarrow$ lietuvių ir 61 lietuvių $\rightarrow$ vokiečiu kalbų bei 24 anglų $\rightarrow$ lietuvių ir 28 lietuvių $\rightarrow$ anglų kalbų padėkos raiškos pavyzdžių.

10) Esu labai patenkinta Jūsų tiksliu ir konkrečiu atsakymu, taigi labai Jums ačiū.

I am very satisfied with your very precise and concrete answer, so thank you very much indeed.

11) Esu labai patenkinta Jūsų tiksliu ir konkrečiu atsakymu, taigi labai Jums ačiū.

Ich bin mit Ihrer sehr präzisen und konkreten Antwort sehr zufrieden, haben Sie vielen Dank dafür.

12) Mr President, thank you very much for these two reports - which we can evaluate as being for the new Parliament and, probably, for the current Commission still, as well as for the new Commission...

Gerb. pirmininke, ačiū jums labai už šiuos du pranešimus - kuriuos mes galime vertinti kaip skirtus naujam Parlamentui ir galbūt vis dar esamai Komisijai, taip pat naujajai Komisijai...

13) Gerb. pirmininke, ačiū jums labai už šiuos du pranešimus - kuriuos mes galime vertinti kaip skirtus naujam Parlamentui ir galbūt vis dar esamai Komisijai, taip pat naujajai Komisijai...

Herr Präsident, ich möchte mich sehr für diese zwei Berichte bedanken, die dem neuen Parlament und wahrscheinlich noch der derzeitigen und der neuen Kommission zur Evaluierung vorgelegt werden...

14) Thank you so much for being here with us.

Labai dèkoju, kad buvote su mumis.

15) Ir nuoširdžiai dèkoju jam už jo rūpinimąsi.

I sincerely thank him for his care.

16) Zunächst auch von meiner Seite ein ganz herzliches Dankeschön an den Berichterstatter, Klaus-Heiner Lehne, der hervorragende Arbeit geleistet hat...

Pirmiausia labai dèkoju pranešèjui K. H. Lehniui už nuostabu darbq̨.

17) Labai ačiū, pone Pirmininke.

Vielen herzlichen Dank, Herr Präsident.

Straipsnyje remiamasi Elizavetos Kotorovos (2013a, 2013) ir jos bei Wolfgango Gladrowo (2015, 2017) požiūriu ị pagrindinị komunikacijos vienetą - šnekos aktą, kurị jie apibrèžia kaip unifikuotą šnekos elgesio modeli (ŠEM) (rus. модель речевого поведения (МРП), vok. Sprachhandlungsmuster, angl. speech behavior pattern). Tai struktūruotas tą pati komunikacini 
tikslą turinčių pasakymų rinkinys. Annos Wierzbickos (1972, 1985, 1987; 1991) semantinès metakalbos ir semantiniu primityvu teorijos ${ }^{14}$ pagrindu autoriai teigia, kad ilokucinis ŠEM turinys ir sandara yra universalūs. Raiška atskirose kalbose (gali skirtis) skiriasi, (gali būti) lemiama skirtingų kultūrų ${ }^{15}$ I I vieną ar kitą ŠEM įeinantys tarpusavyje susiję pasakymai sudaro sistemą - komunikacini-pragmatini lauką ${ }^{16}$, kurio dominantė - adresanto komunikacinis tikslas, būdingas visiems to lauko elementams ${ }^{17}$. Raiškos požiūriu lauko struktūra yra graduota: jị sudaro prototipinès (centro) ir (labiau) periferinès raiškos priemonès. Pavyzdžiui, komunikaciniųpragmatinių pasisveikinimo ir padèkos laukų raiškos prototipai rusų ir vokiečių kalbose skiriasi (Здравствуŭme! resp. Guten Tag! Hallo!; Cnacuбo resp. danke) ${ }^{18}$. Kiekvienoje bendravimo situacijoje adresantas, atsižvelgęs ị komunikacinį ŠEM tikslą, komunikacinius-pragmatinius veiksnius ir struktūrą ${ }^{19}$, iš komunikacinio-pragmatinio lauko viena ar kita kalba pasirenka labiausiai (ati)tinkanti pasakymą. Tokia ŠEM kaip šnekos akto samprata pasirodė paranki kalbėti apie galimas (LINGUEE pagrindu) lietuvių, anglų, vokiečių kalbų padėkos raiškų ir žodžių tvarkos jose koreliacijas ir (arba) skirtumus.

Adresanto pozicija, santykis su pranešimo turiniu ir su tuo, kam pranešimas skiriamas, rašto kalboje matyti iš aktualiosios sakinio skaidos ${ }^{20}$ - sakinio dalių skirstymo pagal jų informacijos krūvị. Skirtingose kalbose aktualiosios sakinio skaidos raiškos priemonès gali būti tapačios ir (arba) skirtingos (pvz.: Lambrecht 1994; Holvoet 2003: 91t; Griškevičienė 2008; Vaskelienè 2015 ir ten cituojama literatūra). Jolantos Vaskelienès (2015) nuomone, pagrindiniai

${ }^{14}$ Pagal semantinių primityvų teoriją, Anna Wierzbicka (1987: 214) padèkos šnekos aktą apibrèžia taip:

„I know that you have done something that is good for me.

I say: I feel something good towards you because of that.

I say this because I want to cause you to know what I feel towards you.

I assume that you would want to hear me say this to you".

Plg.: „I know: you did something good for me; I feel something good towards you because of this; I say this because I want you to feel something good“ (Wierzbicka 1991: 157)

${ }^{15}$ Apie skirtingų kultūrų įtaką lietuvių ir anglų prašymų strategijoms pasirinkti plačiau žr. Hilbig (2009); apie rusų ir vokiečių padėkos strategijas žr. Kotorova (2013); apie švedų ir lenkų, vokiečių padèkos strategijas žr. Zborowski (2005) ir ten gausiai cituojamą literatūrą.

16 „Под термином «коммуникативно-прагматическое поле» понимается соответственно взаимосвязь языковых моделей высказываний в рамках одной и той же стратегии коммуникативного действия“ (Kotorova 2013a: 60).

17 „Коммуникативно-прагматические поля соединяют инвентарь разнообразных грамматических, лексических, словообразовательных, топологических и просодических средств, служащих для выражения определённой иллокутивной цели“ (Gladrow, Kotorova 2015: 32).

18 „Одна и та же иллокутивная цель может быть в разных языках и культурах выражена разными средствами, также распределение средств по полю может зависеть от языка и культуры. В этом смысле полевая модель является удобным инструментом для сопоставительного анализа, она может обеспечить наглядные результаты“ (Kotorova 2013a: 64; dar apie tai žr. Kotorova 2013).

19 „В составе полной перформативной формулы можно выделить, как правило, четыре составляющих: компоненту Действия, компоненту Говорящего, компоненту Адресата и компоненту Повода (для совершения речевого акта). <..> Каждая из составляющих перформативной формулы может иметь сходства и различия в грамматическом оформлении в каждом из сопоставляемых языков“ (Gladrow, Kotorova 2015: 31t).

${ }^{20}$ Teorinių darbų apie aktualiąją sakinio skaidą apžvalgą žr. Vaskelienė (2015) ir ten cituojamą literatūrą. 
lietuvių kalbos sakinių aktualiosios skaidos rodikliai yra neutralioji ir inversinė žodžių tvarka bei loginis kirtis. Axelis Holvoetas (2003: 91) mini tris aktualiosios skaidos raiškos priemones: intonaciją, segmentinius rodiklius (tai) ir žodžių tvarką. Pastarąja autorius naudojasi kaip pagrindiniu rodikliu, bet pripažįsta, kad „tik dalis žodžių tvarkos reiškinių atspindi aktualiosios skaidos skirtumus“ (Holvoet 2003: 98). Be šių aktualiosios skaidos raiškos priemonių, Knudas Lambrechtas (1994: 6tt) dar kalba apie sakinio struktūros (aktyvas vs. pasyvas), funkciniu sakinių tipų (konstatuojamieji resp. klausiamieji resp. šaukiamieji), leksinių vienetų pasirinkimo ir ju statuso sakinyje (plg. mano mašina sugedo; man sugedo mašina) kriterijus.

Vytautas Ambrazas Dabartines lietuviu kalbos gramatikoje (DLKG 1996: 645) teigia, kad „[1]ietuvių kalbos žodžių tvarka daugiausia priklauso nuo jų sintaksinių ryšių bei prasminių santykių sakinyje ir nuo aktualiosios sakinio skaidos, nuo bendraujant kylančių poreikių išryškinti bei pabrèžti tam tikras sakinio dalis“. DLKG skiriami neutralūs ir inversiniai laisvos žodžių tvarkos modeliai. Neutraliuose laisvos žodžių tvarkos modeliuose ,žodžiai išdėstomi pagal ịprastinius ju vartojimo polinkius ir adresatas į tokią tvarką neverčiamas kreipti dėmesio“ (DLKG 1996: 646). Tokie žodžiu tvarkos modeliai yra stilistiškai nežymėti. Pavyzdžiui, „,[n]etiesioginis papildinys dažniausiai eina prieš tiesioginį“, o būdo prieveiksmių ir atitinkamos reikšmès linksnių formų bei prielinksninių konstrukcijų „,neutrali ir vyraujanti vieta - prieš veiksmažodic“ (DLKG 1996: 651, 653; Ambrazas 1982: 107) (žr. 18-19 sakinius; plg. 3 sakinị).

18) Jis atleidžia marčiai visus iki šiol padarytus nemalonumus. (cituojama iš DLKG 1996: 651)

19) [Aš] nuoširdžiai dèkoju šios gimnazijos direktoriui G. V. už pakvietimą. DLKT

Inversiniai, t. y. stilistiškai žymèti, modeliai yra sąlygojami konteksto, kalbos situacijos. Inversinè yra būdo aplinkybès vieta po veiksmažodžio (žinau gerai, pasake aiškiai) ${ }^{21}$ arba derinamojo pažyminio vieta po daiktavardžio (tèvyne brangioji, namai pamiršti) ${ }^{22}$ (Ambrazas 1982: 108; DLKG 1996: 653tt; Pikčilingis 2010: 192tt). „Sintaksiškai susijusios žodžiu grupès dažniausiai atskiriamos tada, kai norima kuriuos nors jų žodžius pabrèžti, suteikti jiems didesnị

${ }^{21}$ Plg. „Vèl kitas, kažkur girdèjęs, kad mūsų kalbai netinką prieveiksmiai sakinio gale, reikia ar nereikia, visada sukilnoja prieveiksmius prieš veiksmažodị, nors kartais ir dẻl pačios sakinio sandaros, ir ypač dẻl logikos kirčio tas prieveiksmis kaip tik turi būti gale. Tuo būdu kartais, ir turint gerų norų, gali būti niveliuojamas kalbos ịvairumas ir lankstumas“ (Žirgulys 1962: 10).

${ }^{22}$,Sudètiniame sakinyje sukeisti pažyminio ir pažymimojo žodžio vietą, kai reikejjo, nevengè ir Jablonskis.

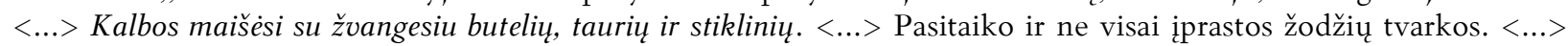
Tuomet seniesiems Europos gyventojams naujas prasidejo gyvenimas. <...> Jei būtų nežinoma, kad šie sakiniai yra J. Jablonskio, tur būt, kai kas šoktų jų gerinti, ypač taisyti tos „netikusios“ žodžių tvarkos“ (Žirgulys 1962: 13t). 
reikšmès krūvị, ir todèl jie atkeliami ị sakinio pradžią ar nukeliami ị pabaigą“ (DLKG 1996: 646; dar žr. t. p.: 653; Ambrazas 1982: 107t; Pikčilingis 2010: 191²3; Žirgulys 1962: 14) (žr. 20-21 sakinius, plg. 7 ir 4 sakinius).

20) Meisteris aš joks nesu. (cituojama iš DLKG 1996: 646)

21) Mes gyvenam gerai. (cituojama iš DLKG 1996: 653)

Vieno ar kito (neutralaus ar inversinio) žodžių tvarkos modelio pasirinkimas labai priklauso nuo aktualiosios sakinio skaidos - temos ir remos. „Bendravimo požiūriu rema yra svarbiausia pasakymo dalis. <..> Dažniausiai tema pasakoma prieš remą ${ }^{24}$. Rema, kurią norima pasakyti anksčiau, sakinio pradžioje, pabrèžiama ar išskiriama tam tikra intonacija arba inversine žodžių tvarka ${ }^{25 ، ~(D L K G ~ 1996: ~ 646 t ; ~ d a r ~ z ̌ r . ~ A m b r a z a s ~ 1982 ; ~ V a s k e l i e n e ̇ ~ 2015) . ~}$

Remiantis A. Holvoetu (2009: 23), manytina, kad ,iš dviejų situacijos dalyvių - gyvo, asmeninio agento ir jo veiksmą patiriančio negyvo patiento (Jonas varto laikrašti ) - kalbètojas universaliai bus linkęs tema pasirinkti agentą (kad ir dèl empatijos principo) (šis polinkis yra žinomas kaip topicworthiness - inherentinis temiškumas)“. Taigi pagal neutralios žodžių tvarkos ir aktualiosios sakinio skaidos koreliaciją lietuvių kalbos sakiniuose galima teigti, kad ,subjektas yra nežymėtos temos sugramatinimo rezultatas, o nežymèta tema, savo ruožtu, remiasi su agentyvumu ir gyvumu susijusiu inherentinius temiškumu“ (Holvoet 2009: 25), ir kelti prielaidą, kad pagal 21-ą sakini (Mes gyvenam gerai) galima pagrịsti padèkos raiškas $(=4)$ dèkoju iš visos širdies, (=1) ačiū širdingai, o (ne)tinkamai vartojamas (=2) nuoširdus ačiū, matyt, susijęs su daiktavardine (=8) nuoširdi padèka (žr. toliau).

Straipsnyje laikomasi nuomonès, kad rašte pasirinkta padèkos raiška gali būti paaiškinama kaip pragmatiškai motyvuota (Lambrecht 1994: 11t, 29, 41); einama nuo struktūros prie pragmatikos. Adresantas, norėdamas verbalizuoti savo komunikacines intencijas, nekuria naujų struktūrų, bet kūrybingai ir kompetentingai naudojasi esančiomis toje kalboje (plg. Lambrecht 1994: 26tt, 31).

Tyrime taikomi aprašomasis, lyginamasis, sintaksinès-semantinès analizės metodai.

${ }^{23}$, ,[K]iekviena sakinio dalis, šiaip ar taip, turi vieną, įprastinę, tik jai būdingą vietą, kurią pakeitus, žodis iggyja tam tikrą akcentą - intonaciškai pakinta visas sakinys. Ir tat nesunku paaiškinti: mūsų akys visuomet nukryps i tą žodị, kuris pavartotas lyg ir ne savo vietoje. Vadinasi, kas šnekant išreiškiama balso pakèlimu, intonacija, rašytinèje kalboje išryškinama įprastinès žodžių tvarkos pakeitimu, arba inversija“ (Pikčilingis 2010: 191).

${ }^{24}$ Tai parode ir J. Vaskelienès (2015) pristatytas empirinis tyrimas, kur remiamasi 35 valandų trukmès įvairių tekstų iૃrašų medžiaga, tema eina prieš remą 77 proc. visų išanalizuotų sakinių.

25 „Ištyrus įvairių stilių tekstų 26066 sakinius paaiškèjo, kad <...>10 proc. rema eina prieš temą, 13 proc. sakinių, kuriuose pateikta vien nauja informacija, laikytini rema“ (Vaskelienè 2015: 90). „Pastarojo modelio sakiniai dažnesni meninio ir buitinio stilių, dialoginès kalbos tekstuose“ (t. p.: 97). 


\section{PADÉKOS SEMANTIKA}

Komunikaciniu aspektu padèkos konstrukcijos - tai pasakymai, kur padèka žymima kaip mandagaus elgesio tarp komunikantuc (adresanto ir adresato) modelis (strategija). Kaip, cituodama kitus autorius, rašo G. Čepaitienè (2007: 180), „padèka turi aiškų ilokucini tikslą: pasakymu siekiama, kad adresatas suvoktų, jog adresantas vertina tai, ką adresatas yra anksčiau atlikęs“ arba dar žada atlikti, „ir už šiuos adresato veiksmus $<\ldots>$ jaučia dèkingumą“. Vadinasi, padèka - tai adresanto reakcija ị buvusị arba būsimą adresato veiksmą (plg. Wunderlich 1976: 77, 83). Adresantas, norèdamas adresatui išreikšti savo dėkingumo jausmą - padèką ${ }^{26}$, ją turi sukurti taip, kad padèkos „ištarimas padarytų kalbètojo intenciją atpažistamą pagal aplinkybes“ (Zaikauskas 2000: 157) ${ }^{27}$. Padèka kuria ypatingą komunikacinio akto atmosferą, kuriai „,būdingas ne vien mandagumas, bet ir draugiškumas, palankumas, nuoširdumas. <...> Visais atvejais, kai reiškiama padèka, adresantas užima arba žemesnę, arba tik jam [adresatui] lygią hierarchinę poziciją“ (Čepaitienè 2007: 180t; plg. Czachur 2006: 20tt; Jakaitienė 2010: 158).

Aptardama padèkos raišką G. Čepaitienè (2007: 182) atkreipia dèmesị i t padèkos esminiu

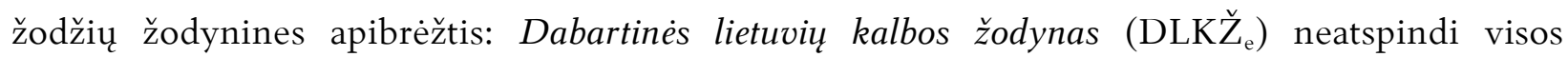
performatyviojo dèkoti semantinès struktūros. Veiksmažodžio dèkoti ir daiktavardžio padèka apibrèžtyse, skirtingai nei priešdèlinio padèkoti „pareikšti padèką, pasakyti dèkui“, nèra minima kalbejjimo sema, kuri rodo, kad dèkingumo jausmas (iš)reiškiamas kalba.

Čia svarbus tampa ir būdvardis dèkingas, -a, kuris žodynuose (DLKŽ $\check{e}_{\mathrm{e}}$, Bendrinès lietuvių kalbos žodyne (BLKŽ $\check{\mathrm{e}})$, Lietuvių kalbos žodyne $\left.\left(\mathrm{LKŽ}_{\mathrm{e}}\right)\right)$ teikiamas kaip „,reiškiantis ar jaučiantis ${ }^{28}$ padèką“, pavyzdžiui, Jis dèkingas man už pagalbą; Iki šiol jaučiuosi jam dèkinga už patarima (dar žr. 6-7 sakinius). Aptariamasis būdvardis, be minètos kalbejjimo, turi ir pozityvios jausenos semą. Adresantas turi pagrindo (tipiškai teigiamą motyvą) jaustis / būti dẻkingas adresatui kaip savo pozityvios būsenos sukèlèjui (plg. Kotorova 2013: 417).

Piotras Zborowskis (2004: 159t, 2005: 53tt; plg. Kotorova 2013: 417), atsižvelgdamas i tai, kad kalbose dèkojimą reiškiantys veiksmažodžiai etimologiškai yra artimai susiję su galvojimą, mintị reiškiančiais daiktavardžiais (plg.: vok. danken ir Gedanke, angl. thank ir think, švedų tacka ir tack), teigia, jog semantinèje tokių veiksmažodžių struktūroje glūdi pozityvios

\footnotetext{
${ }^{26} \mathrm{Plg}$. LKŽ $\check{\mathrm{e}}_{\mathrm{e}}$ : padèka - dèkingumo jausmo už padarytą gerą parodymas, padèkojimas.

Plg. DLKŽ : padèka - dèkingumo reiškimas, padèkojimas.

${ }^{27}$ Plg.: ,[T] he speaker influences the hearer's mental representation of the world“ (Lambrecht 1994: 43).

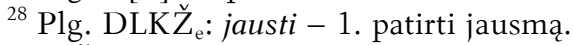

BLKŽ ${ }_{\mathrm{e}}$ : jausti - 1. patirti koki jausmą, pojūtį.

Veiksmažodžio jausti junglumą (valentingumą) žr. Sližienė (1994: 324).
} 
minties sema: „kažkam dèkoti - kažką [geromis] mintimis apdovanoti, paprasčiau, gerų minčių

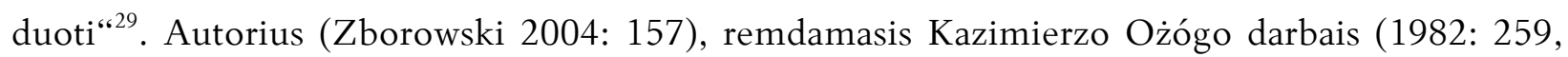
1992: 51tt), kreipia dèmesị ir į tai, kad padèka ir jos raiška implikuoja ir veiksmažodžio norèti ${ }^{30}$ semantiką. Pagal kalbos etiketą, adresantas, eksplikuodamas adresatui savo dèkingumo jausmą, pavyzdžiui, performatyviuoju dèkoju, taip pat implikuoja „noriu, kad tu žinotum, kad tau dèkoju“. Noro semą galima eksplikuoti: tada greta veiksmažodinio performatyvo vartojamas jo ilokucinę galią sušvelninantis modalinis norèti (noriu / norèčiau / norisi Jums padèkoti; plg. trokštu nuoširdžiai padèkoti). Pagal noro analogiją minètina ir semantiniame padèkos lauke esanti pareigõs, kaip moralès įstatymais grịstos būtinybès, reikiamybès, sema (turiu / privalau / reikia Jums padèkoti; turiu / turèčiau būti Jums labai dèkingas; jaučiu pareiga padèkoti ${ }^{31}$ ir pan.) (pvz.: Čepaitienè 2014: 6; Kotorova 2013: 418tt; Zborowski 2005: 17tt, 85tt, 91tt, 133tt, 156tt).

Taigi remiantis tuo, kas trumpai sakyta, padèka kaip šnekos aktas - tai teigiama adresanto būsena, pereinanti (galinti pereiti ${ }^{32}$ ) ì teigiamą (davimo) veiksmą. Tam tikroje situacijoje adresantas visų pirma jaučia adresatui dèkingumą tam tikru teigiamu pagrindu. Norėdamas, kad adresatas tai (su)žinotų ir atsižvelgęs ị tai, kas padèkos situacijoje atrodo aktualiausia, dèkingumo jausmą (širdyje ${ }^{33}$ ) kiek įmanoma tiksliau „,paverčia“ pozityvia mintimi ${ }^{34}$ ir savo padèką tam tikra kalbine forma dovanoja kaip atlygi ${ }^{35}$ už adresato padarytą gera (t. y. atlieka kalbėjimo veiksmą) (esu labai dèkingas; nuoširdžiai dèkoju; dèkui ar pan.) (plg. inter alia Czachur 2006: 20tt; Huber

29 „Jemandem danken - ‘jemanden mit [guten] Gedanken beschenken’, oder noch einfacher: 'jemandem [gute] Gedanken geben'“ (Zborowski 2004: 159).

Plg. rusų kalbos veiksmažodžio благодарить „dèkoti“ darybą: дарить + благо, t. y. dovanoti gèrị.

${ }^{30}$ Veiksmažodžio noréti junglumą žr. Sližienè (1998: 20). vertimą.

${ }^{31}$ Plg. DLKT sakinius: Jaučiu malonia pareiga padèkoti A. M., peržiūrèjusiam ir autorizavusiam knygos

Tomo redaktoriams belieka maloni pareiga padèkoti Gramatikos skyriaus seminarų dalyviams - pranešéjams ir klausytojams - už kūrybines diskusijas.

${ }^{32}$ Plg. DLKT sakinius: Ir tuomet taip akivaizdžiai suvokiau, kad mano gyvenimas ana tolima nakti priklause nuo šio vargano kuproto žmogaus, kuriam niekada neišdrịsiu padèkoti, nes neišdrịsiu prieiti ir užkalbinti... Likau viena.

Frodas paèmé buteliuka ir, šiam tvykstelëjus, vèl pamatè Galadriele karališkai nuostabia, bet nebegrèsmingą. Hobitas nusilenkè, nerasdamas žodžiu padèkoti.

To žodžio nerandu iki šiol, nors labai noriu padèkoti visiems mane prižiūrëjusiems Pasvalio gydytojams, ypač vyr. gydytojui.

${ }^{33}$ Plg. DLKT sakinius:

Vaikystè prie tèvų buvo laiminga, tik trumpa. Širdyje savo tèvams esu labai dèkinga. Jie mane be diržo ir rykščiu išmoke darbo, saž̌iningumo, meilès savo žemei, kuri mus maitino.

Jis kalbejo labai ramiai, ir pasijutau iš visos širdies dèkinga, kad elgiasi su manimi kaip su suaugusia, be tèvišku pamokslų.

${ }^{34}$ Plg. DLKT sakinį: Gerai, kad galima ne tik pavalgyti ir pasisotinti, bet ir paskanauti, ivertinti bei mintyse padèkoti tiems, kurie siūlo mums patikusị kasdienị stebukla.

${ }^{35}$ Plg. DLKT sakinius: Kodèl gi, nedèkingas žmogau?!, - sušuko senoji moteris. - Aš duodu tau tokiq dovana, o tu net nesi dèkingas! Ko gi norètum, kad aš tau duočiau? Galiu išpildyti viena tavo nora.

Kaip Visuotinès Bažnyčios Ganytojas, jūsų maldu lydimas, ateinu sudèti $\boldsymbol{i}$ motiniškas Marijos rankas savo padèkq ir prašymus. 
2005: 8; Kotorova 2013: 417t; Searle 1976: 107; Zborowski 2004: 161tt, 2005: 52tt ${ }^{36}$ ). Pavyzdžiui, neutralios žodžiu tvarkos sakinio Labai dèkoju A. J. už rašinį apie M. K. veikla (DLKT) tipiškas subjektas (numanomas vienaskaitos asmeninis įvardis $a s ̌)$ atitinka dvisluoksnę - veiksmo atlikejjo (agento [A]) ir psichinès būsenos (percipiento [Pcp]) - funkciją ${ }^{37}$. Adresantas, atsižvelgęs ir $\mathfrak{i}$ tai, kas ir kaip padèkos situacijoje aktualu, iš komunikacinio-pragmatinio lauko renkasi padèkos raišką ir ja aktualizuoja dèkingumo būseną resp. veiksmą, plg.: Aš [Pcp] jaučiuosi ${ }^{38}$ dèkingas; Aš $[\mathrm{Pcp}]$ noriu padekoti; Aš $\left[\mathrm{Pcp}_{\mathrm{A}}\right]$ esu dékingas ${ }^{39} ;$ Aš $\left[\mathrm{A}_{\mathrm{P}_{\mathrm{cp}}}\right]$ dèkoju Jums; Aš $[\mathrm{A}]$ tariu $^{40}$ Jums padèka. Tais atvejais, kai dèkojant adresantui svarbu aktualizuoti ir savo būseną, ir veiksmą, jis renkasi vartoti, pavyzdžiui, Didžiai dèkinga dèkoju (DLKT), ir atvirkščiai: kai tai nèra svarbu, vartoja gramatiniu požiūriu nuasmenintą $A$ či $\bar{u}^{41}$. Kaip rašo Waldemaras Czachuras (2006: 20; plg. Kotorova 2013: 417), kuo daugiau adresantas iš adresato gauna, tuo stipriau turi per padèką reaguoti, t. y. adresantas turi būti ypatingai, išraiškingai mandagus ${ }^{42}$. Gramatiškai kalbant, tokiais atvejais adresantas kuria ir vartoja labiau žymėtas padèkos raiškas - su modifikatoriais ir (arba) inversine žodžiu tvarka (dèkoju / dèkui resp. labai dèkoju / dèkui; dèkoju / dèkui labai) (žr. toliau).

${ }^{36}$ Plg. semantinius padèkos šnekos akto komponentus pagal Piotrą Zborowskį (2005: 59):

„1. Ich weiß, dass du etwas Gutes für mich getan hast, oder:

dass du mir etwas Gutes gegeben hast.

2. Ich sage: ich fühle deswegen etwas Gutes dir gegenüber/habe gute Gedanken über dich; dir denke,

3. Ich will dir das zu verstehen geben: (A) Ich will, dass du weißt, was ich dir gegenüber fühle/was ich von

oder: (B) Ich will dir meine guten Gefühle/Gedanken geben,

4. Ich setze voraus, (A) dass du davon wissen willst. (B) dass du meine guten Gefühle/Gedanken annimmst/empfängst.“

Dar plg. 14 išnašą.

${ }^{37}$ Plačiau apie semantinių funkcijų kaip dvisluoksnių sampratą, kuria čia remiamasi, žr. Drukteinis (2009).

Plg. Sližienè (1994: 173).

${ }^{38}$ Veiksmažodžio jaustis valentingumą žr. Sližienė (1994: 324).

${ }^{39}$ G. Čepaitienè (2014: 2) teigia, kad „čia aktualizuojama netiesioginè reikšmè, t. y. pasakymas esu (būsiu) dèkingas vartojamas vietoj performatyvinio pasakymo dèkoju ir yra jam lygiavertis. Konstrukcija esu (būsiu; būčiau) dèkingas (-a) gali pakeisti veiksmažodị dèkoju visose pozicijose“.

${ }^{40}$ Veiksmažodžio tarti valentingumą žr. Sližienè (2004: 302).

${ }^{41}$ Plg. Vito Labučio (1998: 137) vadinamojo benario sakinio (kaip kvazisakinio) sampratą.

${ }^{42}$,Je gewichtiger die Gabe war, desto stärker soll der Höflichkeitsgehalt der anerkennenden Reaktion qua Dank sein. Je nach Einschätzungen der Gewichtigkeit des Dankesobjekts kann demnach auch der Dankesakt als eine mehr oder weniger aufwendige „Arbeit“ auf der Handlungs- und der Ausdrucksebene angesehen werden. Zumal Danken jedoch von einem reaktiven Charakter geprägt ist, erfolgt diese Arbeit unmittelbar nach dem Gebenstransfer, welches ein reales Geschehen darstellt" (Czachur 2006: 20). 


\section{PADE்KOS RAIŠKA PAGAL KALBOS DALI}

3.1. Pagal raišką lietuvių kalbos performatyvus, turinčius savo branduolị ir periferiją, Egidijus Zaikauskas (2002: 80) skirsto ì A) grynuosius (klasikinius), B) mišriuosius, C) daiktavardinius, D) sutartinius (performatyvines formules) ir E) dialoginius. Kiekvienas ju turiss po keletą rūšių. Remiantis E. Zaikausko klasifikacija, šiame straipsnyje toliau nagrinèjamos padèkos raiškos atitiktų A) tipo asmenines veiksmažodžio formas (dèkoju), B) tipo veiksmažodinių daiktavardžių junginius (reiškiu, tariu padèka), C) - vieną daiktavardị (padèka) ir D) tipo - etiketinių funkcijų ištiktukus (dèkui, ači $\left.\bar{u}^{43}\right)$. Autorius nemini būdvardžio performatyvų (esu dèkingas), kurie pagal reiškiu padèka analogiją, regis, galètų būti priskiriami prie mišriujų. G. Čepaitienè (2007: 182tt) padèkas aptaria pagal tai, ar jos žymimos performatyviojo dékoti formomis, jaustukais ar be performatyviojo veiksmažodžio, t. y. konstrukcijomis su daiktavardžiu (padèka) arba būdvardžiu (dèkingas, $-a$ ).

Šiame straipsnyje padėkos konstrukcijos aptariamos pagal esminio žodžio kalbos dalį ${ }^{44}$. Visų pirma kalbama apie tokias, kur sakinio predikatini centrą sudaro esamojo laiko vienaskaitos pirmojo asmens dèkoti forma ${ }^{45}$, paskui - apie būdvardžio dèkingas, - $a$ predikatyvus su esamojo laiko vienaskaitos pirmojo asmens veiksmažodžio formomis (esu dèkingas). Vèliau nagrinèjama padèka, reiškiama daiktavardžiu padèka su modifikatoriais (nuoširdi padèka; reiškiu nuoširdžia padèka). Galiausiai aptariamos padèkos su dèkui.

Pagal valentingumą padẻkos esminiai žodžiai yra trivalenčiai, t. y. savo reikšmės pagrindu atveriantys tris laisvas vietas, kurias, be subjekto vardininko arba kilmininko (aš esu dèkingas; nuoširdi mano padèka), sakinyje užima beneficiento (adresato) naudininkas ir motyvo (kaip veiksmo arba būsenos pamato, pagrindo) prielinksnio $u z ̌$ su galininku konstrukcija arba šalutinis sakinio dėmuo (Sližienė 1994: 173). Bendraudamas adresantas padèkos raišką kaip tam tikrą

43 Žodžių ačiū, dèkui priskirtis kalbos dalims skiriasi. Juozas Pikčilingis lietuvių kalbos gramatikose nekaitomus ačiū, dèkui laiko jaustukais, kurie „sintaksiškai dažniausiai traktuojami ne kaip viena ar kita sakinio dalis, o tik kaip jos (arba viso sakinio) pakaitalas“ (LKG 1971: 728t, DLKG 1996: 464). Tapačios nuomonès laikosi ir Adelè Valeckienè (1998: 200) Funkcinëje lietuvių kalbos gramatikoje. Ačiū, dèkui kaip jaustukai teikiami ir DLKŽ BLKŽ ${ }_{\mathrm{e}}$. Kalbamieji žodžiai LKŽ ${ }_{\mathrm{e}}$ yra su interj. pažyma, apimančia ir jaustukus, ir ištiktukus. Ištiktukais ačiū, dèkui vadina E. Zaikauskas (2002). O Juozas Pabrèža (2017: 99) žemaičių ačiū, dèkui priskiria prieveiksmiams (plg. Ulvydas 1955: 28, 1957: 135t; cituojama iš Ulvydas 2000: 176t, 223).

${ }_{44}$ Plg. „Lietuvių kalboje padèkų pagrindą sudaro veiksmažodis dèkoti, iš jo sudaryti būdvardžiai, daiktavardžiai ir jaustukai dèkui, ačiü““ (Jakaitienè 2010: 159).

45 „Patogiausia priemonè eksplicitiškai išreikšti ilokucinę jègą, kad būtų išvengta klaidingo pasakymo ilokucinio tikslo interpretavimo, - pasakymas su performatyviuoju veiksmažodžiu, pavartotu tam tikra gramatine forma, - vadinamasis „,eksplicitinis performatyvas““ “(Zaikauskas 2000: 158).

Dar plg.: „Esamasis laikas žymi, kad veiksmas vyksta tik pačiu kalbamuoju momentu ir savo trukme nesiekia nei praeities, nei ateities. <..> veiksmas atliekamas pačiu veiksmažodžio ištarimu ar jo parašymu. $<\ldots>$ Šios reikšmès ypač būdingos pirmojo asmens formoms“ (DLKG 1996: 295t). 
strategiją renkasi tokią, kad ji jam garantuotu sèkmingą ilokuciją - padèkos šnekos aktą ${ }^{46}$. Pagal adresanto pasirinktą strategiją ilokucinį tikslą pasiekti padèkos raiška varijuoja nuo maksimalios (su eksplikuotais visais sintaksiniais esminio žodžio aktantais) iki minimalios (arba maksimaliai redukuotos, kai laisvos valentinių aktantų vietos užpildomos iš konteksto) ${ }^{47}$ (plg. 22-31 sakinius).

22) A. T. Aš dèkoju deputatams už sunkų ir tikriausiai nuobodų darbą, kaip sakè deputatas V.P.

23) Tèvynei pašaukus jie iš tų jaukių, jau savais tapusių lizdu grįžo atiduoti savo patirties ir meilès. Dèkoju Dievui už laime pažinti vienq iš ju.

24) Č. J. Gerbiamieji kolegos, aš jums dèkoju. Noriu atkreipti dèmesị i naujaji Seimo leidini „Seimo kronika“.

25) - O Garbingoji Tauta! Aš to net tikètis nedrisau, - apsidžiaugè Frodas, o Semas iš laimès tiesiog žado neteko. - Dékoju tau, o Gildorai Inglorionai! - pasaké Frodas nusilenkdamas.

26) Ar ruošiate kokias nors reformas ir kaip jūs žadate atgaivinti miesta ir kaima? Dèkoju.

L. M. S. Aš dèkoju už klausimq, bet, mano supratimu, tai visos Vyriausybès problema, o ne tik mūsų ministerijos.

27) Atsiprašau, kad taip vèlai skambinu, tikriausiai pažadinau? - blaškosi nuo minties prie minties Eva. - Ne, nepažadinai, - mègina nuraminti ja Nora. - Dėkoju už pasitikèjimq, dèkoju, kad pakvietète, bet... Bet aš nedirbsiu. Atleiskit, negaliu. - Dèl Laimos laiško? - Ne. Ne tik dèl jo...

30) Tokiu būdu tas klausimas palengvès ir, man atrodo, nebereikètu jo kelti čia kaip nesuderinto. PIRMININKAS. Aš dèkoju. Ponas G. B. dar patikslina ir baigiam.

31) Metęs žvilgsnị i kabantị žaliq Dvalino gobtuvą. Savo raudonaji jis pasikabino šalia ir pridejjęs ranka prie širdies taré: - Balinas, jūsu paslaugoms! - Dèkoju (plg. dèkui)! - atsaké visiškai apstulbęs Bilbas.

Čia, kaip minèta, svarbu ne tiek valentiniai aktantai, kiek vadinamieji laisvieji nariai modifikatoriai kaip padèkos intensifikatoriai (plg. 1-17, 19 sakinius). Pagal modifikatoriaus

${ }^{46}$ Apie padėkos raiškas ir adresanto strategijas plačiau žr. Ożóg (1982, 1992).

${ }^{47}$ G. Č epaitienè (2007: 182tt), skirtingai nei šio straipsnio autorè, atskaitos tašku ima komunikacini padèkos pasakymų aspektą ir padèkos pasakymus aptaria pradėdama nuo maksimaliai redukuotų (dèkoju, ačiū ir pan.). 
kategorinę raišką ir vietą padèkos esminio žodžio atžvilgiu turimi DLKT duomenys suskirstyti 1oje lentelèje. Iš šios lentelès matyti, kad inversinè žodžių tvarka padèkos konstrukcijoje (dèkoju nuoširdžiai; nuoširdžiai esu dèkingas; dèkui labai) sudaro mažumą visų turimų pavyzdžių (6,6 proc., arba 53 atvejai iš 800$)$, dar retesnè yra nuoširdus, didelis dèkui vartosena (3,8 proc. arba 30 sakinių iš 800$)^{48}$.

1 LENTELE். Modifikatoriaus raiška ir vieta greta padèkos esminio žodžio (EŽ)

\begin{tabular}{|c|c|c|c|c|c|}
\hline \multirow{2}{*}{$\begin{array}{l}\text { Modifikatoriaus } \\
\text { kategorinè } \\
\text { raiška ir vieta } \\
\text { EŽ atžvilgiu }\end{array}$} & \multicolumn{4}{|c|}{ Padėkos EŽ } & \multirow[b]{2}{*}{ Iš viso } \\
\hline & $\begin{array}{c}\text { Veiksmažodis } \\
\text { dekkoju }\end{array}$ & $\begin{array}{c}\text { Būdvardis } \\
\text { dékingas, }-a\end{array}$ & $\begin{array}{c}\text { Daiktavardis } \\
\text { padèka, }-q\end{array}$ & $\begin{array}{l}\text { Jaustukas } \\
\text { ačiū, dèkui }\end{array}$ & \\
\hline nuoširdžiai EŽ & $\begin{array}{c}112(93,3 \\
\text { proc.) }\end{array}$ & $\begin{array}{c}246(87,9 \\
\text { proc. })\end{array}$ & - & $\begin{array}{c}229(84,8 \\
\text { proc.) }\end{array}$ & $\begin{array}{c}587(73,4 \\
\text { proc.) }\end{array}$ \\
\hline EŽ nuoširdžiai & 8 (6,7 proc.) & $\begin{array}{c}34^{49}(12,1 \\
\text { proc. })\end{array}$ & - & $\begin{array}{l}11(4,1 \\
\text { proc. })\end{array}$ & $\begin{array}{l}53(6,6 \\
\text { proc. })\end{array}$ \\
\hline $\begin{array}{c}\text { nuoširdus, }-u \\
\text { EŽ }\end{array}$ & - & - & - & $\begin{array}{l}30(11,1 \\
\text { proc.) }\end{array}$ & $\begin{array}{l}30(3,8 \\
\text { proc. })\end{array}$ \\
\hline nuoširdi,-iq EŽ & - & - & $\begin{array}{c}130(100 \\
\text { proc.) }\end{array}$ & - & $\begin{array}{c}130(16,2 \\
\text { proc.) }\end{array}$ \\
\hline Iš viso: & $\begin{array}{c}120(100 \\
\text { proc.) }\end{array}$ & $\begin{array}{c}280(100 \\
\text { proc.) }\end{array}$ & $\begin{array}{c}130(100 \\
\text { proc.) }\end{array}$ & $\begin{array}{c}270(100 \\
\text { proc.) }\end{array}$ & $\begin{array}{c}800(100 \\
\text { proc.) }\end{array}$ \\
\hline
\end{tabular}

3.2. 32-33-iame sakiniuose matyti neutrali būdo modifikatorių vieta - tarp subjekto ir predikato (tarinio). Esamojo laiko pirmojo asmens forma (dèkoju) rodo, kad padèkos veiksmas atliekamas kalbėjimo momentu. Žodžių tvarkos atžvilgiu panašus yra 34-as sakinys. Tačiau čia vartojamas segmentinis rodiklis tai rodytų, kad subjektas (aš) yra ne tema, bet kontrastinè rema, panašiai kaip, tarkim, būtų sakinyje Jums labai dèkoju aš (o ne kas kitas) (plačiau žr. Holvoet 2003: 91t; dar žr. toliau). 35-38 sakiniai yra su numanomu vienaskaitos pirmojo asmens subjektu (aš). Jo pozicijoje pasakomi modifikatoriai yra pabrěžiami (labai, labai arba labai labai): vartojami, kad adresatas atkreiptų dèmesị ne ị patị adresantą $(a s ̌)$ ar padèkos veiksmą (dèkoju), bet ị pastarojo

${ }^{48}$ Remiantis P. Zborowskio (2005: 75tt) lenkų, švedų kalbų padėkos pasakymų tyrimu, teigtina, kad tai, jog adresantas vienaip ar kitaip žymėtą padėkos strategiją renkasi retai, yra (proto)tipiška.

Dar žr. 25 išnašą.

${ }^{49}$ Čia teikiami būdvardžio predikatyvo inversijos atvejai nuoširdžiai esu dékingas. 
kokybės ir kiekio ${ }^{50}$ intensyvumą (plg. labai ${ }^{51}$ didele $^{52}$ padéka). Tai akivaizdu 37-ame sakinyje, kur tarp intonaciškai vienį sudarančių būdo (kiekio) modifikatorių (labai labai) ir predikato ịsiterpia inversinis beneficiento naudininkas (jums) ${ }^{53}$. Panašiai galètų būti interpretuojamas 38-as sakinys: sakinio pradžioje vartojamas modifikatorius nuoširdžiai pabrèžia padèkos būdą ir kiekị (tariu dar vieną padèką), pasakomą jungtuku ir (dèkoju ir už tai). Padèkos veiksmo būdas taip pat gali būti paryškinamas modifikatorių nukeliant po predikato arba dar toliau - į sakinio pabaigą. Tai matyti 39-42-ame sakiniuose (dar žr. 4 sakinį). Be to, 41-42-o sakinių padèką galima interpretuoti ir kitaip: adresantas pabrèžia ne padèkos intensifikatorių, pasakomą širdingai / iš visos širdies, bet patị veiksmą - dèkoju (plg. tai dèkoju iš visos širdies).

32) J. Š. Gerbiamieji deputatai, aš labai dèkoju deputatui A. T., kuris atsiliepè j̇ mūsų frakcijos parengta nutarimo projektq. Tiesa, kai kurios nuostatos nevisiškai sutampa.

33) H. K. Gerbiamasis pirmininke ir gerbiamieji deputatai, aš labai dèkoju už suteikta žodį. Noréčiau paaiškinti du dalykus.

34) Greitai prabègtume visas veiklos sritis, nes kiekvienas tas žodis paliečia šimtus žmoniu ir paliečia ištisas veiklos sritis bei šakas. Tai aš labai dèkoju, jeigu mes galètume... Jūs tiesiog jeigu galètumèt paklausti, ar nèra pastabu dèl šio papunkčio, aš būčiau labai dèkingas.

35) - Iš tikrųų? - Garantuoju! Virëjos veidas nušvito, buvo įdomu stebèti, kaip širdgèla virsta didžiu džiaugsmu. - Labai, labai dèkoju! - ji padave Helai šalma ir rakteli. - Jūs mano angelas, - taré ji, bet po to trumpam susimastè. - O ar jūs mokate naudotis? - Turiu toki namuose!

36) „Kaip jums negèda, jam juk skauda, jis verkia“ (vaikui pasidaro gaila siaubūno), ir išvale krokodilui dantis. Krokodilas padèkojo: „Labai labai dèkoju tau“. Žiūrédamas filmuka vaikas gauna žiniu apie tam tikru gyvūnu bruožus, ypatybes (krokodilo letenèlès per trumpos, kad pats galetu valytis dantis).

37) Gal galètumète mane išleisti? - Ką? Dabar? Darbo valandomis? Ka jūs galvojate? Griežtai draudžiu! - Kaip malonu. Labai labai jums dèkoju.

\footnotetext{
${ }^{50}$ Dar plg. DLKT sakinị: - Liudmila, tai, ką dabar pasakei, yra labai vertinga detalè mano tyrimams. Tūkstantị kartų tau dèkoju. Ar iš tikrųjų esi įsitikinusi, kad tas žmogus nejuokavo? - Šimtu procentų ne!

${ }^{51}$ Plg.: DLKŽ : labai - 1. nepaprastai, ypač; 2 didžiai, smarkiai; daug; 3. Tikrai, visiškai.

${ }^{52}$ Plg.: DLKŽ $\check{\mathrm{e}}_{\mathrm{e}}$ : didelis - 1. žymus savo apimtimi, dydžiu; 3. gausus, apstus; 4. smarkus, stiprus.

${ }^{53}$ Plg.: „Apskritai paèmus, labiau pabréžiamos tos sakinio dalys, taip pat ir aplinkybės, kurios atkeliamos i sakinio pradžią arba, priešingai, nustumiamos ị jo galą. Pavyzdžiui, Saulès aš pasiilgau. <...> Akcentuojamas žodis saule - papildinys“ (Pikčilingis 2010: 195).
} 
38) Sprendžiant iš aukso svorio, akivaizdu, kad jūs gerokai patuštinote savo kišenes. Nuoširdžiai jums dèkoju ir už tai. Dabar darysime štai ką. Išsinuomosime laiva, nuplauksime i Šiaurę, surasime vaikus ir juos išvaduosime ${ }^{54}$.

39) Mano tèvai, kurie auklëjo mane labai laisvai ir su meile (už ka aš jiems dèkoju iš visos širdies), už galvu susièmè, kai, baigęs devynmetę ir sulaukęs vos aštuoniolikos metų, netikètai pareiškiau jiems, kad esu priimtas dirbti.

40) Jo plienine dvasia ir granito valia šiandien tapo jo kūnu ir simboliu prie šios karo mokyklos sienos. Jaučiu jūsų meilę ir dèkoju šeimos vardu nuoširdžiai, noreikiškai „vètriškai““ (plg. jaučiu jūsų meilę ir nuoširdžiai dèkoju šeimos vardu).

41) Ko gero, dabar galvojate, kaip tyliai nusigauti prie kelto, ar ne? - Galvoju, - prisipažino Frodas, - nors galvoti nèra ko - reikia eiti, ir viskas. Dèkoju širdingai jums už svetingumą! Nepatikèsite, misteri Kurmrausi, bet jūsu ir jūsų šunu aš trisdešimt metu bijojau. Be reikalo, žinoma.

42) - Kodèl neįsivaizduoju? Viska puikiausiai įsivaizduoju, gerbiamoji mm... - Meilè, prisistatè moteris. - Ir dèkoju iš visos širdies. Patikèkite manimi, Meile! - Kodèl „,patikèkite manimi“"? - nustebo moteris. - Juk aiškiu aiškiausiai pasakiau, kad jumis tikiu.

Analogiškai adresantas renkasi inversiją, kai nori atkreipti adresato dėmesį ị savo dèkingumo būsenos intensyvumą ir dèkoja pasirinkdamas būdvardžio predikatyvo su esu konstrukcijas. Tada, kaip matyti iš 43-47-o sakinių, būdo modifikatoriai, skirtingai nei neutralios žodžių tvarkos 48-50-ame sakiniuose, pasakomi prieš tarinio jungti, t. y. subjekto (aš) vietoje.

43) „,Didžiai esu dèkingas Dievui, kurio valia lèmè man visq mano gyvenima būti siekimu žmogumi“.

44) - Kam tokiam esate sukūręs labai gražius laiptų turèklus? - Vaistininkui. Ir jam labai esu dèkingas. Tokia užsimezgè draugystè, kad jis net mano steigti meno darbu įmonę. Jo pavardès skelbti negaliu.

45) Algi, nuoširdžiai esu Tau dèkingas už tai, kad aplankei mane ligoninëje tuo metu, kai nuotaika tikrai buvo pakaruokliška. Ypač dèkingas esu Tau už palikta knyga „Duonq ir debesis“.

\section{Jūsų laiške.}

${ }^{54}$ Plg. DLKT sakinị: Baigdamas, mielas p. Ž., dar karta nuoširdžiausiai dèkoju už paguodos ir vilties žodžius 
46) Jau nebe juokais esu dèkingas anam saugumiečiui, kuris parodè, kad galima kitaip perskaityti raidę ir žodị. Tas galioja ir Dievo raštui.

47) Kai buvau maža, pažinojau tokiq vieną bobq. Labai jai esu dèkinga. Ji buvo vardu Anelè, o ją šaukdavo „Mano Angele“, ir gal ji iš tikruju buvo ištremtas angelas, ị gérimu parduotuvę.

48) Apie pradžiq man nesunku pasakoti - ji įsirèžusi i gyvenimą. Esu be galo dèkingas savo tėvams. Jiems dèkingas už visas gyvenimo pamokas, ịvykusias iki 20-ojo gimtadienio.

49) - Esu labai dèkingas jums, ponia. Mes vis dar kylame. Manau, kuri laika dar reikès skristi aukštyn.

50) Aš iš visos širdies dèkingas visam savo varganumui ir liguistumui, viskam, kas tik yra manyje netobula, dèl to, kad tai man palieka šimtus landu, pro kurias galiu pabègti.

Dar labiau adresanto dẻkingumo būsenos intensyvumas pabrèžiamas šaukiamuosiuose 51-54-ame sakiniuose, kur pačioje sakinio pradžioje vartojamas būdo kaip arba klausiamasis koks, -ia (plg. dar 55 sakini).

51) Taip, Jèzau... kai atëjo laikas kalbèti apie vaisius, Tu nutilai... Kaip aš Tau dèkingas už tai (plg. O kaip labai aš Tau dèkingas!)! Juk tikrai - viskas ka galiu - tai leisti Tau manyje išlaikyti savo Žodị ${ }^{55}$.

52) Aš netikiu jokiais dievais. Aš tikiu Pasauliu. Taigi, mielas Pasauli, kaip aš Tau dèkinga, kad esu. Kad galejau džiaugtis vaikystès vaivorykštès spalvomis.

53) - Turi omeny Jaspera? - susivokè Jolanta. - Malina, jis ne-i-ti-ké-ti-nas! Kai pagalvoju, kad galëjau ištekèt už Viktoro... Kokia aš tau dèkinga (plg. Labai aš tau dèkinga!)! Tik dabar sužinojau, kas yra tikras gyvenimas. Tiesiog jaučiu... - ... pavasarinio vëjo gūsị, ką? užbaigèm abi su Eva.

54) - Nè neįsivaizduojate, koks esu jums dèkingas. - Nèr už kq. Man nęitikètinai patinka, kad jums visos dienos atrodo skirtingos, man jos visiškai vienodos.

${ }_{55}$ Plg. dar DLKT sakinị: Visi ypač pamilome Petro Cvirkos, Salomëjos Nèries bei kitų rašytojų kūrinèlius vaikams. Labiausiai esu mokytojai dèkingas už iskiepyta meile knygai (plg. O labiausiai esu mokytojai dèkingas už iskiepyta meilę knygai!). Ši meile, neišblèsusi iki šiol tolimesniame mano gyvenime buvo ypač svarbi, nes iš knygu teko išmokti tai, ko neišgirdau. 
55) - Diana, baik, nekalbèk taip, aš myliu tave, tu man esi pati brangiausia, aš esu taip dèkinga (plg. aš esu tokia dèkinga) likimui, kad sutikau tave... - Zuzana apsiašarojo sakydama šiuos žodžius.

Adresanto dẻkingumo būsenos tęstinumas 56-ame sakinyje pabrèžiamas laiko modifikatoriu (ligi grabo lentos) pasakant sakinio pabaigoje, t. y. iškeliant laiko aplinkybę iš iprastos jos vietos sakinio pradžioje. O 57-58-ame sakiniuose vartojami tipiški laiko reikšmès modifikatoriai (visq gyvenimą, amžinai ${ }^{56}$ ) gali būti interpretuojami kaip būdo (plg. be galo ${ }^{57}$ dèkinga). Atsižvelgiant ì tai, visai įmanoma, kad padèkos intensifikatoriai, vartojami su būdvardžio predikatyvu, gali būti pasakomi ne tik pagal 43-47-o sakinių analogiją (be galo, amžinai esu dèkingas), bet ir pagal 56-ą sakini, pavyzdžiui, Aš tau esu dèkingas be galo, amžinai, kur modifikatoriai be galo, amžinai turètų sinkretinę: laiko (,nuolat“) ir būdo bei kiekio (,tikrai“; „labai“ ${ }^{58}$ ), reikšmę (dar plg. 59-ą sakinį). Sinkretinė reikšmė blokuojama, kai laiko modifikatorius sakinyje pasakomas (žr. 60-61 sakinius).

56) Mano gyvenimo ratas apsisuko. Tai visų gražiausias mano knygos - tavo būsimos monografijos - puslapis... Aš myliu tave. Aš tau dèkingas ligi grabo lentos (plg. visada / visa gyvenima tau esu ir būsiu (liksiu) dèkingas) ir mirsiu tavyje ir su tavim dar daug daug sykių... Tu mano Nora. Tu mano Heda, tu mano Barbora, tu mano Madam Bovari...

57) - Aš jai už tai buvau ir būsiu visq gyvenimq dèkinga (plg. aš jai buvau [esu] ir būsiu be galo dèkinga), - tvirtina Julija.

58) Taip šita mergina išmokè mane skaityti. Jos pavardè Uršulè Bakšinskaitè. Aš jai esu amžinai dèkinga (plg. aš jai esu labai / be galo dèkinga), dažnai už ja pasimeldžiu.

\footnotetext{
${ }^{56}$ Plg. LKŽ $\check{\mathrm{e}}_{\mathrm{e}}$ amžinas - 2. nenustojantis egzistuoti. 3. visiškas, tikras, didelis: Susirgo amžinai (labai sunkiai)
} Ps.

${ }^{57} \mathrm{Plg}$. LKŽ : galas - 5. mažas kokio daikto gabalas: Davèm ir jam žemès galeli (sklypeli) bulbèm pasisodint Ėr. Nesurūkyk, palik man gala [papiroso]! Dbk. 8. pabaiga: Reikia klausyti nuo pradžios lig galiai Gmž. ^ Be galo nebus galo Upn.

$\mathrm{FŽ}_{\mathrm{e}}$ : be gãlo - 1. labai: Be galo didelis rš. Be galo jis nori pralobti Gs. Pintardos tokios raibuotos, be galo (plg. daug) deda Krž. 2. ilgai: Rodos eičiau taip be galo Varn.

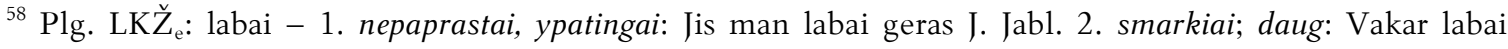
privargau J. Jabl. 
59) Noriu, kad šiam laiškui nebūtų kliūčiu Jus pasiekti. Būsiu be galo (plg. visada; labai) ir iš širdies (plg. nuoširdžiai) dèkingas už man parūpinima ir toliau Lietuvos filosofiniu leidinių, nes dabar ju gavimas labai pasunkèjęs. Visi geri linkëjimai Jums ir Žmonai ${ }^{59}$.

60) Kaip ten ịvyktų, ar pasisektų man ištrūkti iš Europos, ar ne, Jums visada būsiu be galo dèkingas už jau dabar padarytus žygius mano reikalu. Atleiskite, kad ir aš esu vienas iš tų, kurie savo prašymais duzinu Jums galva, bet padettis yra tokia.

61) Kartais toks išsikalbëjimas mane sukrečia iki ašarų. Kartais savo pašnekovui jaučiuosi be galo dèkinga ir dar labiau - skolinga, nes gavau nęikainojama atvirumo dovana.

Tada, kai dèkodamas adresantas pabrèžia pačią dèkingumo būseną, pats būdvardžio predikatyvas (dèkingas, $-a$ ) pasakomas inversiškai, t. y. prieš tarinio jungti (žr. 62-63 sakinius; plg. 43-47 sakinius). Kai inversiškai pasakoma dèkingumo būsena yra išskirtinè, tai reiškiama taip, kaip matyti 64-66-ame sakiniuose: būdo modifikatoriai vartojami būdvardžio predikatyvo prepozicijoje arba postpozicijoje (plg. 42 sakini).

62) Mes su ja maloniai pasikalbame apie vaikystès išdaigas ir dabartini nelengva pensininko gyvenimą. Dèkingas esu ir savo žmonai Elenai, sūnaus Gintauto šeimai.

63) Šiq operacija, matyt, atliks jau kita karta, pati neịsipainiojusi j kompromisinius ano istorinio laiko žaidimus. Dèkingas esu Jums už recenzija - už pagyrimus, kurių ta knyga gal ir nenusipelnè, ir ypač už kritika iš Vakaru kultūros taško.

64) Labiausiai dèkingas esu treneriui Z. V. ir savo tèveliui, kurie mane privertè nemesti šios sporto šakos, atkakliai treniruotis.

65) Juk aš nematydavau, kas ant lentos parašyta, žemèlapio spalvu neskirdavau. Kai kurie mokytojai padèdavo. Ypač dèkinga esu istorijos mokytojai $A$. V.

66) - Mielasis daktare, - bylojo daktarè, - tarp mūsų daug mažiau prieštaravimu, nei jūs manote. Juk ir aš myliu jị. Juk ir man gaila jo kaip jums. O dèkinga jam esu daugiau nei jūs (plg. O dèkinga jam esu labai; labiau, nei manote). Be jo neturéčiau čia tokios geros vietos.

${ }^{59}$ Plg. dar DLKT sakini su dèkoju, kur neutralioje vietoje einantis jo modifikatorius yra pabrèžiamas: Paskutine kvailè, tikëjau, kad dar atsigaus. Tik, kai kunigas paskutini patepima davé, supratau, kad jau viskas. Tada buvo likusi savaite. Ir be galo (plg. nuolat; ypač; daug) dèkoju Dievui, kad buvo man užrišęs akis, kad padëjo eiti iki galo... Begalinis ačiū seselei Nijolei, kuri kasdien ateidavo perrišti Nijolei žaizdos. 
Kaip minėta, padėka reiškiama ir veiksmažodiniu daiktavardžiu padèka su modifikatoriais, kurie turimuose DLKT pavyzdžiuose vartojami tipiškai - prepoziciciškai (nuoširdi padèka). Iš 6774-o sakinių matyti, kad padekka eina pasakyto arba numanomo esamojo laiko vienaskaitos pirmojo asmens veiksmažodžio valentiniu aktantu - subjektu arba tiesioginiu objektu, kuris 6771-ame sakiniuose, skirtingai nei 72-74-ame sakiniuose, pasakytas inversiškai.

67) Dabartinèmis sq̨lygomis ji viena iš svarbiausių šlovingo atminimo nešèju ir puoselètojų. Jai tenka $^{60}$ didžiausia padèka, kad senajame Lietuvos krašte išliko vienokia ar kitokia pačios sampratos „Lietuvos žydai“ perspektyva.

68) Ne vien a. a. O. Š. gelbëjo žydu gyvybes, bet ir kiti lietuviai, ne vienq mane, bet ir daugiau. Jiems visiems priklauso mano nuoširdžiausia padèka (plg. mano nuoširdžiausia padèka priklauso jums visiems ${ }^{61}$ ).

69) Čekai, konkurso organizatoriai, kurie vienintelius kauniečius atleido nuo būtino muzikiniu varžytuvių nario mokesčio. Visiems jiems - nuoširdžiausia padèka!

70) - Kaip laikaisi? - Normaliai, - neutraliu tonu atsiliepé Geraltas. - Net pusantro reikalo sugebëjau prasukti. - Už vaikq - ypatinga padèka (plg. už vaika yra / tenka ypatinga padèka; ypatinga padèka [yra] už vaika), - linktelëjo Vesemiras.

71) Universiteto prorektoriui prof. P. Z., geranoriškais patarimais nuoširdžiai padëjusiems tobulinti monografijos rankraštị. Išskirtinę padèkq reiškiu tiems, kurie padëjo šiq knyga techniškai parengti (plg. reiškiu išskirtinę padèka tiems, kurie padëjo).

72) - Kad Centras veiktų, vien geru noru ir entuziazmo nepakanka. Mūsu iniciatyvos ir programos nebūtu igyvendinamos be rèmëjų. Nuoširdžiausia padèka jiems visiems. Pasakoja centro vadove K. O. P. (dar plg. 8 sakini)

73) Prieš trejus metus Kauno medicinos universiteto klinikose buvau gydytas dèl išeminès ligos. Jaučiu gilia padèka gydytojui kardiochirurgui A. S., tada padëjusiam man išsikapstyti iš sunkios širdies kraujagysliu trombozés ligos.

74) Reiškiu (plg. tariu, sakau) nuoširdžia padèkq visiems savo draugams, kolegoms už atviruma, tiesuma, išsakytas idëjas ir norą bendradarbiauti.

${ }^{60}$ Plg.: LKŽ $\check{\mathrm{e}}_{\mathrm{e}}$ tikti - 9. pasitaikyti, būti.

${ }^{61}$ Plg. DLKT sakini su neutralia žodžių tvarka: Apskritai visiems, kurie moraliai parèmè ir kitaip padëjo išleisti šiq „,byla“. Atskira padèka priklauso mano žmonai Birutei ir vaikams Aistei, Monikai, Donatui, supratingai leidusiems savaitgaliais tūnoti bibliotekoje arba nekreipti j juos dèmesio. 
Reta išimtis 75-as sakinys, kur inversiškai vartojamas nederinamasis daiktavardžio padekka modifikatorius (padèka širdžių) galètų būti žymimas ir derinamuoju (priimki padèkq širdinga / nuoširdžia).

75) Viešpatie, priimki padèkq mūs širdžiu (plg. priimki mūsų širdžiu padèką; priimki padèka širdinga)! Koks garbingas pašaukimas nešti kitiems šviesa ir meilę, skelbti Viešpaties Žodi, gyventi su Juo ir Jame.

Jaustukai dèkui, ačiū „,nepavadina ilokucinès jègos“, bet dar aiškiau nei dèkoju „rodo ilokucinę jègą“ (Zaikauskas 2002: 91; plg. Čepaitienė 2007: 191). Iš 76-87 sakinių aiškèja, kad performatyviajam veiksmažodžiui ir (arba) predikatiškai vartojamam dèkingas, $-a$ artimi ačiū, dèkui vartojami pagal anksčiau aptartų sakinių analogiją. İprastą vietą pakeitęs modifikatorius arba padèkos jaustukas yra pabrěžiamas (žr. 83-86 sakinius). Pavyzdžiui, 85-ame sakinyje vartojamas inversinis modifikatorius (širdingai) pabrèžia padèkos, pasakomos jaustuku ačiū, intensyvumą (t. y. ačiū (ne bet kaip, bet) širdingai), o 86-o sakinio modifikatorius (labai) vartojamas po jaustuko (dèkui) dèl to, kad pastarasis yra išskiriamas, taip kaip 87-ame ar 78-82 sakiniuose neutralioje vietoje pasakomas modifikatorius labai ir pan. Galiausiai 88-ame sakinyje matyti prepoziciškai (labai) ir postpoziciškai (iš visos širdies) vartojami jaustuko ačiū modifikatoriai, kurie, reikšdami skirtingą padèkos intensyvumą, yra pabrèžiami, t. y. neutrali žodžių tvarka (labai $a c ̌ i u \overline{)}$ yra žymèta.

76) Vienu trūktelëjimu jis nuplèše narvo spyną, atidarè mažas dureles ir iškèle žmogutį. Nuolankiausiai dèkui (plg. nuolankiausiai dèkoju)! - tarè mažylis ir nusilenkè berniukui. Gal galetumete pakelti mane iki spynos?

77) Galiu teigti, kad mano šeimyninis gyvenimas susitvarkè. Ruošiausi daug metu tam žingsniui, tačiau viena karta reikëjo jam ryžtis. Todèl labai nuoširdžiai ačiū (plg. labai nuoširdžiai dèkoju) (plg. 59 sakini).

78) Vairavo Bekas. - Jaučiau, kad geriau likti namie. - Taigi labai tau dèkui už rūpestị (plg. taigi labai tau dèkoju / dèkingas už rūpestị), - pasake Krisas, apsimesdamas ìsižeidusiu. Nedrịstu nè pagalvoti, kas būtų atsitikę, jei būčiau buvęs vienas. 
79) - Kaip gerai, kad atsiliepèt jūs, - pro ašaras nusišypso Vaira. - Aš dar būčiau nesusivaldžiusi, iškoneveikusi ją ir viskq sugadinusi. Dèkui jums, Klausai, labai labai jums dèkui. Klausas tik linkteli ir išeina ${ }^{62}$.

80) Bet kai dabar močiutè Gison atsistojo priešais jị ir su jai būdingu orumu taré: „Iš širdies dèkui už gražias mišias (plg. iš širdies dèkoju už gražias mišias), pone klebone!", jis dar nuožulniau pagulde savo galvutę ant peties ir tik skèstelëjo rankomis.

81) Da neužmiršes... Meliuoracija? Taip nieka i nier, nie kuokiuos giminies? - Ten nèra. Yra brolis, bet jis kitur gyvena... Jau jums taip dèkui (plg. jau jums taip (labai) dèkoju; taip (labai) dèkingas), kad nežinau. Tikrai, stebuklas, pats Dievas jus atsiuntè. Kaip dabar aš jums atsilyginsiu? - Martyno ranka jau kilo prie švarko kišenès, bet staiga.

82) O šauksmo to turinys taigi toks: - Mat kaip Tu, Dieve, viska matai, kaip Tu viska matai ir kaip supranti. Kaip dèkui, kaip ačiū (plg. Kaip / taip (koks / toks) dèkingas, kaip / taip (koks / toks labai) dèkingas!)! Matei Tu tą mano apuoką. Taigi tikrai, tai tikrai iš tikruju nei jis ten sekmadieniais dirbdavo, nei kq.

83) Kalendoriumi, ir „,M - vieno“ rašiklis, ir , $M$ - vieno“ lipduku kolekcija. - Valio valio! Valio valio valio! Noriu palinkèt tau geros gražios dienos. - Dèkui labai jums. - Ačiū ir tau. Tuo tarpu Deimante? - Taip. - Jeigu pasigarsinsi radija, tai žinok, kad daina, kuri dabar skambès m viene - yra skiriama būtent tau. - Gerai. Dèkui labai. - Ačiū tau. Iki.

84) Šiuo atveju vèl Agnè užsidirba tašką. Yra du - nulis, ir Agne tau, kaip jau esu minëjęs, atitenka Lumene produktų rinkinys. - Dèkui labai. - Dékui ir tau. Geros, gražios dienos. Tuo tarpu Svetlana? - Taip. - Jeigu pasigarsinsi radija, tai daina skambès būtent tau, gerai? - Dékui.

85) - Gal iš tikro duokit, panèšèsiu kiek. - Ačiū, ačiū širdingai. Sakau, kad mes, laukininkai, ipratę. O tamsta, jaučiu, ne žemès knisejjas. - Iš ko jaučiat? - Iš balso. Iš ko gi daugiau?

86) Ministrę ir svarstyti toliau biudžeto projektą, suteikti žodị Biudžeto komisijos pirmininkui, frakcijoms, komisijoms ir taip toliau. Sutinkate? Tai ${ }^{63}$ dèkui labai (plg. tai dèkoju labai). E. K. Ačiū jums. PIRMININKAS. Prašau ị tribūna gerbiamaji Biudžeto komisijos pirmininkq A. $R \cdot{ }^{64}$

${ }^{62}$ Dar žr. panašiai pabrěžiamą labai DLKT sakinyje: Šeimininkè vèl nedrąsiai praveré duris ir ant stalo padeda garuojantị valgyma. - Dèkui, labai dèkui. Dar nelabai gi norëjau, - dèkoja mokytojas mieguisto vaiko akimis.

${ }^{63} \mathrm{Plg}$. LKŽ 2. daikto ypatybès ar veiksmo intensyvumui pabrěžti: Tai nusisekė - kaip šuniui botagas! Plm.

${ }^{64}$ Dar plg. DLKT sakinius, kur tai pabrěžia dèkui, dèkoju: - Et, dèl šito problemu nebus! - regis, lengviau atsipūtè bosas. - Tik su Karidze reikès laika suderinti, bet čia jau smulkmena... - Tai dèkui. Gal galiu eiti? - Benas palengva atsistojo. - Žygiuok, per pietus pasikviesim... 
87) Ir mes tikimès, kad kiekviena proga jūs demonstruosite, kad saugumas visiškai nenori „Naujaja romuvq““ pasmaugti. - Jei taip, tai labai dèkui! Aš, žinoma, labai suinteresuotas, kad didètu „Naujosios romuvos“ prenumeratoriu skaičius. Ir džiaugiuos, kad visi ja užsiprenumeravote $e^{65}$.

88) Pagaliau ovacijos pamažu nuščiūva, žmonès atsisèda $i$ vietas, ir čeku mokslininkas drebančiu balsu taria: - Labai jums ačiū, mano bičiuliai, ačiū iš visos širdies. Nusilenkia ir nueina prie savo kèdès.

Tiriama DLKT medžiaga leidžia manyti, kad tais atvejais, kai jaustukai dèkui, ačiū (gali būti) interpretuojami daiktiškai, jie tampa artimi daiktavardžio padèka su derinamuoju modifikatoriumi konstrukcijoms ${ }^{66}$. Pavyzdžiui, 89-o sakinio labai ačiū panašus į 69-70-ame sakiniuose vartojamas padèkas, pasakomas daiktavardžio konstrukcija (ypatinga / nuoširdžiausia padèka), o 90-92-o sakiniu artimas 74-75-ame sakiniuose predikato objektu einančiam padèka su modifikatoriumi. Tai teigiant, aiškèja nuoširdus dèkui vartosenos priežastys 93-96-ame sakiniuose: daiktavardiškai suvokiamas dèkui eina su juo nežymėta gimine derinamu būdvardžiu. Atsižvelgiant ị tai, galima paaiškinti ir kitas adresanto pasirinktas vartoti nuoširdus dèkui, didelis ačiū ar panašias raiškas, pavyzdžiui, 97-99-ame sakiniuose.

89) Visi artimieji, draugai liko Lietuvoje. Aišku, ilgainiui ir čia susirandi pažįstamu, draugų. Nepažistami žmonès labai daug padëjo. Už tai jiems - labai ačiū! Šiuo metu jie man kaip antroji šeima.

90) Pasirodè tèvelis. Su didele gražiai žylančia patriarcho barzda, tvirto ịdegusio kūno, atrodè amžinas. Pats vedè ekskursiją. „...Sakau labai ačiū (plg. sakau didele padèka) savo naujajam tèvui. Niekada nejaučiau, kad jis netikras tèvelis“, - praslinkus dvidešimtmečiui sakè dukra Jolanta.

91) - Taigi jums turiu būti dèkinga, kad tenka tąsytis po šita Dievo užmiršta užkampị! nusikeikè ji. - Na, tai tariu labai ačiū. Baisiausiai ačiū. - Mums? - pasitikslino Sierakailè.

PIRMININKAS. Aš vis dèlto noriu perspèti, kad jūs neklausiat pranešèjo, taip? V. B. Svarstome, taip. PIRMININKAS. Tai dèkoju gerbiamajam N. R. Jis yra teisus sakydamas, kad negavo po pirmojo svarstymo pataisu.

${ }^{65}$ Dar žr. DLKT sakinį, kur tai pabrèžia modifikatorių labai labai: Mandagiai atsiprašè neturis pinigų, o šoferis dar mandagiau pasake, kad jam pinigu ir nereikia, vis tiek vienas ir tuščias važiavo. - Tai labai labai dèkui, -atsakè vaikas, ir namo jis grižo šįsyk ne taip vèlai.

${ }^{66} \mathrm{Plg}$. J. Pikčilingio nuomonę 43 išnašoje. 
92) Autorius jums, kaip aktoriui, būtu dèkingas, - pasakiau kaip tik galèdamas ramiau. Kas man iš tos padèkos? Dèkui nešk Vaitiekui ${ }^{67}$... (plg. padèkq nešk Vaitiekui) Aš noréčiau, kad jūs parašytumèt Lubiui.

93) Lietuviu kalba iki šiol iš pagrindu ugdè lietuviai kalbininkai, ir jiems už tai priklauso mūsu visu nuoširdus ačiū (plg. priklauso mūsų visų nuoširdi padèka). Ju dalyvavimas vystant kalba bus ne mažiau svarbus ir ateityje. Būtų nesusipratimas, jeigu jie šiuo darbu mažiau domètųsi ar net visai jị apleistų.

94) Veržiasi tuoktis net kitu miestu gyventojai, meilę bei ištikimybę Baltajai gulbei neseniai iš naujo prisiekè ir kauniečiai (už tai jiems - nuoširdus dèkui) bei miesto meras, sukritikavę valdžios kuluaruose pasigirdusius ketinimus Civilinès metrikacijos biurq iškelti i kita miesto vietq“.

95) Dabar - taip tragiškai - Leonidas. Jūsų žodžius perskaičiau pavèluotai. Pavèluotas ir mano nuoširdus ačiū (plg. pavèluota ir mano nuoširdi padèka).

96) Tad mielajam V. A. D. mano nuoširdus dèkui (plg. V. A. D. [tenka / yra (skirta)] mano nuoširdi padèka; mielajam V. A. D. skiriu nuoširdžią padèką ${ }^{68}$ ). Tai talentingo žmogaus rašinys. Noréčiau daugiau apie jị žinoti.

97) Užmokyklinę veikla paremia dori verslininkai, tačiau kuris gi nori tai daryti, jei iš to jokios reklamos, tik nuoširdus ačiū (plg. iš to nèra jokios reklamos, tik [yra] nuoširdi padèka)?.. Ne, dar yra entuziastu, kurie, nekreipdami dèmesio ị nepriteklius, organizuoja, vertina, siūlo... 98) Ypač nuoširdy ačiū tariu dukrai Laurenai (plg. ypač nuoširdžiq padèka tariu dukrai; *урас̌ nuoširdžiai dèkoju tariu dukrai; ?ypač nuoširdžiai dèkingas tariu dukrai), ant mano ofiso vienos sienos parašiusiai: „Tèveli, prašau greičiau baigti rašyti knygą! Skubèk!!!“”

99) Prieš keletą savaičiu buvo čia pas mane ị Grūtą kolūkiečiai suvažiavę, padovanojo šautuva ir pasake dideli ačiū. - Už ka??

${ }^{67}$ Dar plg. DLKT sakinị su daiktavardiškai vartojamu dèkui: Švediškai pasakè, kad man nelabai gerai galvoje. Ka padarysi! Take! Kažkas labai panašaus i dèkui.

${ }^{68} \mathrm{Plg}$. dar DLKT sakinius: Redaktorei G. G., kuri ne tik kvalifikuotai suredagavo ir sutvarkè rankraštį, bet parodè didelị dèmesị knygai išleisti. Padèkos žodžius skiriu savo žmonai Maniai, kuri nuolat palaikè mane dvasiškai ir kantriai, daugybę kartų ranka perrašinëjo rankraščio variantus, sūnui Markui, ypač dukrai.

Paskutinị savo padèkos žodi skiriu savo dviem dukroms, kurios dali kelio buvo mano bendrakeleives, ir savo žmonai Susan - dèl jos meilès gyvenimui ir literatūrai buvo verta keliauti. 
Žinoma, DLKT esama ir tokių, kaip 100-102-as sakiniai, kur konstrukcija nuoširdus / didelis dèkui galètų būti keičiama ị veiksmažodinę nuoširdžiai / labai dèkoju ar pan. Tačiau, matyt, kalbètojo pasirenkama neatsitiktinai.

100) Moksleiviams dvasinès stiprybès suteikè V. A. vadovaujamo Vilniaus universiteto dainu ir šokiu ansamblio labdaros koncertas. Dar kartą nuoširdus dèkui (plg. nuoširdi padèka vs. nuoširdžiai dèkoju / dèkui) Jums, mielieji bičiuliai. Daug padèkos žodžiu pelnè UAB „INMEDA“ kolektyvas, talkinęs renginiuose Vilniuje.

101) Gavau Tavo miela laiškuti, o Tau tik dabar, atbloškusi knygas buhalterines bei kitus popiergalius $\dot{j}$ šona, noriu nors keletą žodžiu parašyti. Pirmiausia didelis dèkui (plg. didelè padèka vs. labai dèkoju / dèkingas / dèkui) už gražų ir miela laiškuti. Džiaugiuosi, kad Tau pas mama gera, kad Tave lepina, kad Tu taisaisi.

102) Tačiau, asmeniškai susipažinęs, aiškiai matau, kad esi žmogus doras ir garbingas, ir jei ka sakai, tai ir tiki, o už tai ir didelis ačiū. Duok Dieve ir dar susitikti, gal net ir pas mus, karčì krienų krašte?

3.3. Atskaitos tašku imant lietuvių kalbos padèkas matyti, kad negausiuose LINGUEE vertimuose iš lietuvių kalbos yra vartojamos raiškos labai dèkoju, labai dèkingas, labai ačiū, kurių tik viena, kaip matyti 103-ame sakinyje, yra inversinè. Aptariamoji ačiū labai konstrukcija išversta ị anglu kalbos thank you very much ir vokiečiu kalbos daiktavardiškąją vielen Dank konstrukciją. Padèkos konstrukcijos su veiksmažodžiu dèkoti ir prepoziciniu modifikatoriumi (labai dèkoju, noriu labai padèkoti) išverstos į anglų kalbos padėkas, reiškiamas veiksmažodžiu, būdvardžiu arba jaustuku (I sincerely thank; I am appreciative; thank you very much) (žr. 104-106 sakinius) bei vokiečiu kalbos veiksmažodines (ich danke sehr), būdvardines (sehr dankbar) ir daiktavardines (vielen / herzlichen Dank) konstrukcijas (žr. 107-109 sakinius) ${ }^{69}$. Lietuvių kalbos didelè padèka verčiama daiktavardinėmis anglu ir vokiečių kalbos konstrukcijomis (eins großes Dankeschön; $a$ big „thank you“), o labai ačiū - į anglų kalbos thank you very much, many thanks arba vokiečių kalbos ich bedanke, möchte herzlich danken; vielen / herzlichen Dank ar pan. Ir atvirkščiai: negausūs LINGUEE duomenys rodo, kad anglų kalbos padèka su veiksmažodžiu (I thank you very much) verčiama lietuvių kalbos performatyviuoju dèkoju (žr. 110 sakinị), thank you very much - i sinonimiškus lietuvių kalbos labai dèkoju, labai ačiū; vokiečių kalbos veiksmažodinè ich danke schön konstrukcija susijusi su lietuvių kalbos labai dèkoju, o daiktavardžiu žymima padèka (ein

${ }^{69}$ Dèl nedidelio LINGUEE pavyzdžių kiekio sakinių, kur vartojamos vienos ar kitos padèkos raiškos, jų skaičius nedetalizuojamas. 
herzliches Dankeschön) - su lietuvių kalbos daiktavardine (didele padèka) arba veiksmažodine (nuoširdžiai dèkoju) raiška; danke sehr verčiamas kaip labai dèkoju / dèkingas / ačiū. Taigi turimi menki vertimų duomenys leistų kalbėti apie tipišką abipusę padėkos raišku su veiksmažodžiu, daiktavardžiu, jaustuku atitiktị atskirose kalbose (t. y. labai dèkoju $\leftrightarrow$ I thank you very much; ich danke sehr; didelè padèka $\leftrightarrow$ a big ,thank you“; vielen herzlichen Dank; labai ačiū $\leftrightarrow$ thank you very much; danke sehr) ir (ar) kitas galimas raiškų koreliacijas (plg. dar 11-17 sakinius), bet nepatvirtina nagrinètų kalbų žodžiu tvarkos įtakos lietuvių kalbos inversinei padėkos raiškai.

103) Negalime leisti, kad po tokio ilgo 7-ojo straipsnio analizavimo proceso valstybinis reguliatorius galètų pasakyti „Ačiū labai už jūsų nuomonę, bet aš liksiu prie savo metodo“ ir paprasčiausiai elgtis taip, tarsi nieko nebūtų nutikę.

... we cannot accept that, having been through the verys lengthy Article 7 review process the notifying national regulator can say 'thank you very much for your point of view, but I prefer my approach'.

... es kann nicht angehen, dass die notifizierende nationale Regulierungsbehörde nach einem sehr langwierigen Überprüfungsverfahren nach Artikel 7 einfach sagen kann: „Vielen Dank für Ihren Standpunkt, aber ich bevorzuge meinen eigenen Ansatz“.

104) [İsipareigojimą] šiandien dar sykị pakartojo Komisijos narys K. De Gucht ir nuoširdžiai dèkoju jam už jo rūpinimasi.

... which was today reiterated by Commissioner De Gucht and I sincerely thank him for his care.

106) Už tai nuoširdžiai dèkoju.

... and for that I am most warmly appreciative.

106) Labai dèkoju, ponia Pirmininke, ir labai ačiū visiems šioje diskusijoje kalbëjusiems nariams.

Thank you very much, Madam President, and thank you very much to all the Members who have spoken during this debate.

107) Labai dèkoju visiems už parama ir noréčiau prisijungti prie Renate Weber ir kitu šešèliniu pranešèjų ir padèkoti Piliečiu laisvių, teisingumo ir vidaus reikalų komiteto sekretoriatui ir visiems patarëjams.

Ich danke Ihnen sehr für all Ihre Unterstützung und möchte mich dem Dank von Renate Weber und den anderen Schattenberichterstattern anschließen, den diese dem 
Sekretariat des Ausschusses für bürgerliche Freiheiten und allen Beratern ausgesprochen haben.

108) Žinoma, labai dèkoju, Parlamentui už šiandienos diskusijas.

Ich bin dem Parlament natürlich sehr dankbar, dass wir heute diese Aussprache geführt haben.

109) Pirma, labai dèkoju mūsų dviem kolegoms Parlamento nariams iš Biudžetų komiteto.

Zunächst herzlichen Dank an unsere beiden Kollegen aus dem Haushaltsausschuss.

110) I thank you very much for all your support.

Labai dèkoju visiems už parama.

\section{APIBENDRINIMAS IR IŠVADOS}

Išnagrinėjus 800-us DLKT pavyzdžių, kur dèkoju, dèkingas, -a, padèka, -q, dèkui, ačiū vartojami su prepoziciniais ir postpoziciniais modifikatoriais, matyti, kad dabartinejje lietuviu kalboje dèkui labai vartojamas pagal dèkoju labai, labai esu dèkingas analogiją, t. y. kūrybingai ir kompetentingai pasirenkant žymètą padèkos raiškos strategiją. Taigi inversinis dèkui labai yra toks pat tinkamas vartoti, kaip ir kiti stilistiškai žymėti raiškos atvejai. Inversinę žodžių tvarką padèkos konstrukcijoje adresantas renkasi retai (6,6 proc. visų atvejų, arba 53 pavyzdžiai iš 800$)$.

Žodžių tvarkos ir aktualiosios sakinio skaidos atžvilgiu ištirtoji medžiaga leidžia sudèlioti tokias padèkos raiškos koreliacijas. Neutralios žodžių tvarkos (in)tranzityviniuose sakiniuose tipiškas vardininku žymimas subjektas (aš) atliepia nežymètą temą, kuri susijusi su vadinamojo inherentinio temiškumo principais: skirtingomis gyvumo, agentyvumo, apibrèžtumo, temiškumo ir pan. vertèmis (Aš nuoširdžiai dèkoju Jums / esu nuoširdžiai dèkingas už pagalba; Aš tariu Jums nuoširdžia padèka). Pagal inherentinį temiškumą netiesioginis naudininko objektas (Jums) antrasis po subjekto vardininko pretenduoja būti sakinio tema. Tada sakinio rema pasakoma netipišku subjektu - abstraktų daiktą žyminčiu daiktavardžiu ((=67) Jai tenka nuoširdžiausia padèka; plg., Jums patinka klasikine muzika). Padèkos esminis žodis arba jo modifikatorius gali būti remizuojamas pasirenkant vartoti veikiamosios resp. neveikiamosios rūšies konstrukcijas (Aš skiriu Jums nuoširdžia padèka resp. Jums skirta mano nuoširdi padèka), šaukiamuosius sakinius ((=39) Dèkoju širdingai jums už svetingumą! (=53) Kokia aš tau dèkinga! (=82) Kaip dèkui, kaip ačiū!). Vartodamas inversinès žodžių tvarkos padèkos konstrukcijas, adresantas pabrèžia patị padèkos esmini žodị (Dèkoju labai), jo valentinị aktantą (Jums (o ne kam kitam) labai dèkoju) arba 
modifikatorių (Jums dèkoju (ne bet kaip, bet) nuoširdžiai). Neutralios žodžių tvarkos atvejais kontrastinę remą rodo tai (Tai labai, labai dèkui).

Negausūs LINGUEE vertimai nepatvirtino nežymètos anglų, vokiečių kalbos žodžių tvarkos įtakos žymètai dèkui labai vartosenai lietuvių kalboje.

Žiūrint ị aktualią dabartinès lietuvių kalbos vartoseną ir pasirenkamas skirtingas padèkos raiškos strategijas dèkingumo būsenai resp. veiksmui (ne)aktualizuoti (esu labai dèkingas resp. labai dèkoju resp. labai dèkui), manytina, kad adresantas didelis / nuoširdus dèkui vartoja daiktiškai suvokiamai padèkai aktualizuoti (plg., (=92) Dèkui nešk Vaitiekui). Toks ì daiktavardžiu pasakomo predikato argumento vietą „lendantis“ ekonomiškas jaustukas ačiū, dèkui žymimas pagal daiktavardžio padèka pavyzdị: būdvardiškasis modifikatorius su ačiū, dèkui yra derinamas, t. y. parenkamas nežymètosios (vyriškosios) giminès būdvardis (didelè padèka resp. didelis dèkui). Žinoma, yra kontekstų, kur konstrukciją didelis / nuoširdus dèkui galima gretinti ir su labai / nuoširdžiai dèkoju. Visgi manytina, kad tais atvejais, kai dèl kalbos ekonomijos, padèkos raiškos aktualizacijos skirtumų (ir) ar kitu priežasčių ačiū, dèkui sakinyje užima performatyviojo dèkoju arba predikatiškai vartojamo dèkingas, -a poziciją, jaustuko modifikatoriai yra (būtų) parenkami pagal pastaruosius (labai / nuoširdžiai dèkoju, labai / nuoširdžiai dèkingas resp. labai / nuoširdžiai $a c ̌ i u \bar{u}, d \dot{e} k u i)^{70}$.

70 Plg.: „Padèkos jaustukai visada atlieka padèkos aktą, yra performatyvinio veiksmažodžio dékoju konkurentai, galintys vienas kitą pakeisti bet kurioje situacijoje, tiek kalbant buitiniu stiliumi, tiek oficialioje aplinkoje“ (Čepaitienė 2014: 2). 


\section{ŠALTINIAI}

$\mathrm{BLKŽ}_{\mathrm{e}}$ - Bendrinès lietuvių kalbos žodynas: elektroninis variantas. Vyr. red. Danutė Liutkevičienė, Vilnius: Lietuvių kalbos institutas, 2015. Prieiga internete http://bkz.lki.lt.

DLKT - Dabartines lietuviu kalbos tekstynas. Sudare Kauno Vytauto Didžiojo universiteto Kompiuterinès lingvistikos centras. Prieiga internete http://donelaitis.vdu.lt.

DLKŽ $_{\mathrm{e}}$ - Dabartinès lietuvių kalbos žodynas. Vyriausiasis redaktorius Stasys Keinys, 7-as pataisytas ir papildytas leidimas. Vilnius: Lietuvių kalbos institutas, 2012, XXVI, 969 p.; elektroninis variantas, 2015. Prieiga internete www.lkiis.lki.lt.

FŽe - Frazeologizmu žodynas. Rengè: Irena Ermanytė, Ona Kažukauskaitė, Gertrūda Naktinienè, Jonas Paulauskas (redagavo), Zita Šimėnaitè, Angelè Vilutytė. Vilnius: Lietuvių kalbos institutas, 2001, XVIII, 886 p.; elektroninis variantas, 2015. Prieiga internete http://1kiis.lki.lt/frazeologizmu.

LINGUEE - Vertimu žodynas: elektroninis variantas. Prieiga internete https://lt.linguee.com/. LKŽ $\check{e}_{\mathrm{e}}$ - Lietuvių kalbos žodynas (t. 1-20, 1941-2002): elektroninis variantas. Redaktorių kolegija: Gertrūda Naktinienė (vyr. redaktorè), Jonas Paulauskas, Ritutė Petrokienè, Vytautas Vitkauskas, Jolanta Zabarskaité, Vilnius: Lietuvių kalbos institutas, 2005 (atnaujinta versija, 2008). Prieiga internete www.lkz.lt.

\section{LITERATŪRA}

A m b ra za s V. 1982: Žodžių tvarka ir baltų kalbų sakinio tipo rekonstrukcija. - Baltistica 18(2), $100-118$.

Czachur W. 2006: Dankesformeln als kulturspezifisches Phänomen im Deutschen und Polnischen. - Acta Philologica 32, 17-32.

Č epaitienè G. 2007: Lietuvių kalbos etiketas: semantika ir pragmatika. Šiauliai: Šiauliuc universiteto leidykla.

Č e paitienè G. 2014: Padèkos raiškos galimybès. - Bendrine kalba 87. Prieiga internete http://www.bendrinekalba.lt/?87 (žiūrèta 201811 15).

DLKG 1996: Dabartinès lietuviu kalbos gramatika, red. V. Ambrazas. Vilnius: Mokslo ir enciklopedijų leidykla.

Druktein is A. 2009: Semantinès sakinių struktūros su sinkretinės reikšmès predikatais. - Res Humanitariae 6, 24-41.

Girdenis A. 1996: Taip šneka tirkšliškiai: Šiaurès žemaičiu telšiškiu tarmès tekstai su komentarais. Vilnius: Mokslo ir enciklopedijų leidykla. 
Gladrow W., K otorova Е. [Гладров В., Которова Е. Г.] 2015: Контрастивное изучение моделей речевого поведения. - Жанры речи 2(12), гл. ред. В. В. Дементьев. Саратовский государственный университет, 27-39.

Gladrow W., Kot orova E. 2017: Kontrastive Untersuchung von Sprachhandlungsmustern. - Zeitschrift für Slawistik: ZfSl 62(3), 365-386.

Griškevičienè A. 2008: Reminių lietuvių kalbos pagrindinių sakinio dalių perteikimas norvegu kalboje. - Kalbotyra 58(3), 25-34.

Hilbi g I. 2009: Lietuvių ir anglų prašymų strategijos ir mandagumas. - Lietuvių kalba 3.

Prieiga internete: http://www.lietuviukalba.lt/index.php/lietuviu-

kalba/article/view/15/117 (žiūrèta 201811 15).

H olv o e t A. 2003: Aktualiosios skaidos problemos. - Sintaksinių ryšiu tyrimai, red. A. Holvoet, A. Judžentis. Vilnius: Lietuviu kalbos institutas, 79-98.

Holvoet A. 2009: Argumentų hierarchijos ir gramatinès funkcijos. - Gramatiniu funkciju prigimtis ir raiška, red. A. Holvoet, R. Mikulskas. Vilnius: Vilniaus universitetas, Asociacija „Academia Salencis“, 1-36.

H u be r A. 2005: Danken heißt denken. - Das Heft vom Danken. Aug. 2005-Nov. 2005.

Prieiga internete http://www.unterschleissheim-

evangelisch.de/downloads/Vielseitig_08_-05.pdf (žiūrèta 201811 15).

Ja ka it i e nè E. 2010: Leksikologija. Vilnius: VU leidykla.

KNK 1991: Kaip nereikia kalbèti, sud. D. Mikulėnienė. Vilnius: Mokslas.

K ot orova E. 2013: Dankesbezeigung im deutschen und russischen Diskurs: soziokulturelle, pragmatische und sprachlich-strukturelle Aspekte. - Zeitschrift für Slawistik: ZfS1 58(4), 417-434.

Kotorova Е. [Которова Е. Г.] 2013а: Коммуникативно-прагматическое поле как метод комплексного описания способов реализации речевых актов. - Томский журнал лИНГ и АНТР 1(1), 58-67.

KP2 (S3) 2009: Kalbos patarimai 2. Sintaksè: İvairūs dalykai (S3), sud. R. Miliūnaitè. Vilnius: Mokslo ir enciklopedijų leidybos institutas.

K uč inskait ė A. 1985: Lietuviu kalbos etiketas. Vilnius: Mokslas.

K u č inska it è A. 1990: Lietuvių kalbos etiketas. 2-asis pataisytas ir papildytas leidimas. Vilnius: Mokslas.

K učinskait ė A. 2007: Kalbos etiketas. - Lietuvių kalbos žinynas, sud. P. Kniūkšta. Kaunas: Šviesa, 486-518.

L a b u t is V. 1998: Lietuvių kalbos sintaksè. Vilnius: Vilniaus universiteto leidykla. 
Lambrecht K. 1994: Information structure and sentence form. Topic, focus, and the mental representations of discourse referents. Cambridge: Cambridge University Press.

LKG 1971: Lietuvių kalbos gramatika 2. Morfologija, red. K. Ulvydas. Vilnius: Mintis.

O żóg K. 1982: Podziękowania w polszczyźnie mówionej. - Język Polski 62(4-5), 259-266.

O ż ó g K. 1992. O niektórych aspektach semantyki zwrotów grzecznościowych. - Polska etykieta językowa [= Jezzk a kultura 6], red. J. Anusiewicz, M. Marcjanik. Wrocław: Wiedza o Kulturze, 51-56.

P a b r è ža J. 2017: Žemaičių kalba ir rašyba. Šiauliai: Šiaulių universitetas.

Pikčilingis J. 2010: Stilistikos darbu rinktine. Vilnius: Mokslo ir enciklopediju leidybos centras.

S e arle J. R. 1976: Sprechakte. Frankfurt am Main: Suhrkamp Verlag.

Sližien è N. 1994: Lietuvių kalbos veiksmažodžiu junglumo žodynas 1. Vilnius: Mokslo ir enciklopedijų leidykla.

Sližien è N. 1998: Lietuvių kalbos veiksmažodžių junglumo žodynas 2(1). Vilnius: Mokslo ir enciklopediju leidykla.

S 1 i ž i e n è N. 2004: Lietuvių kalbos veiksmažodžiu junglumo žodynas 2(2). Vilnius: Lietuvių kalbos instituto leidykla.

Šu kys J. 2003: Kalbos kultūra visiems. Kaunas: Šviesa.

Šu kys J. 2006: Kalbos kultūra visiems. Kaunas: Šviesa.

U1vydas K. 1955: Vienaskaitos įnagininko kilmès prieveiksmiai dabartinèje lietuvių kalboje. - Mokslo darbai. Istorijos ir filologijos mokslu serija 2, 20-63.

Ulvydas K. 1957: Vienaskaitos naudininko prieveiksmèjimas ir prieveiksmiai su formantais (i)ui, -i lietuviu kalboje. - Kai kurie lietuviu kalbos gramatikos klausimai. Straipsniu rinkinys, 115-169.

U1vydas K. 2000: Lietuviu kalbos prieveiksmiai. Vilnius: Mokslo ir enciklopediju leidybos institutas.

Valeckienè A. 1998: Funkciné lietuviu kalbos gramatika. Vilnius: Mokslo ir enciklopediju leidybos institutas.

V a skeli en ė J. 2015: Rašytinio teksto aktualioji sakinio skaida. - Žmogus ir žodis. Didaktine lingvistika 17(1), 87-99.

W ie r z bi cka A. 1972: Act of speech. - A. Wierzbicka, Semantic primitives. Frankfurt am Main: Athenäum Verlag, 122-149.

W ierzbicka A. 1985: A semantic metalanguage for a crosscultural comparison of speech acts and speech genres - Language and society 1, 491-513. 
W i e r z bi cka A. 1987: English speech acts verbs: a semantic dictionary. Sydney: Academic Press.

Wierzbicka A. 1991. Speech acts and speech genres across languages and cultures. A. Wierzbicka, Cross-cultural pragmatics. The semantics of human interaction. Berlin-New York: Mouton de Gruyter, 149-196.

W underlich D. 1976: Studien zur Sprechakttheorie. Frankfurt am Main.

Zaikauskas E. 2000: Leksinis, gramatinis bei pragmatinis performatyvumo pobūdis. Kalbotyra 48(1)-49(1), 157-162.

Z a ika uskas E. 2002: Lietuvių kalbos performatyvų raiška. - Baltu Filoloğija 11(2), 79-96.

Z borowski P. 2004: Einige Bemerkungen zur Semantik der Sprechhandlung Danken im Schwedischen, Polnischen, Deutschen und anderen Sprachen. - Folia Scandinavica 8, $155-167$.

Z borowski P. 2005: Dankbarkeit vs. Höflichkeit und sprachliche Routine. Der Dankakt im Schwedischen verglichen mit Polnisch und Deutsch [= Seria Filologia Skandynawska 11]. Poznań: Adam Mickiewicz University.

Žirgulys A. 1962: Šis tas apie žodžių tvarką. - Kalbos kultūra 3, 10-14. Prieiga internete http://www.bendrinekalba.lt (žiūrèta 201811 15).

Gauta 20190211

Priimta 20191114 


\section{DIDELIS DE்KUI AND DE்KUI LABAI}

\section{IN THE MODERN LITHUANIAN (WRITTEN) LANGUAGE}

\section{Sum mary}

The article deals with the question whether the thank-you constructions dekui (ačiū) labai, nuoširdžiai (thank you very much, with all my heart) and didelis, nuoširdus dèkui (ačiū) (many, sincere thanks) are fit to use in the modern Lithuanian language. The thank-you constructions are addressed in a syntactic-semantic and thematic-rhematic structure aspect. The study relies on material gathered in the Corpus of the Modern Lithuanian Language (CMLL) by the Centre of Computational Linguistics of Vytautas Magnus University and the online translations dictionary LINGUEE.

Analysis of CMLL cases where the Lithuanian words for thanks, dekkoju, dekingas, $-a$, padèka, -q, dèkui, ačiū, are used with prepositional and postpositional modifiers has shown that in the modern Lithuanian language, dekui labai is used by the analogy of dèkoju labai, labai esu dekingas (I am very grateful), which is to say by choosing a marked strategy of expression of thanks in a creative and competent way. The inverse dèkui labai is just as appropriate to use as other stylistically marked cases of expression. The addresser tends to choose an inverse order of words in a thank-you construction rarely (6.6proc. of all cases, or 53 cases out of 800 ).

In terms of word order and thematic-rhematic structure, the subject material allows mapping the following correlations of thank-you expressions. In (in)transitive sentences with neutral word order, the typical subject $(I)$ that is marked by the nominative mirrors an unmarked topic, or theme, that is related to the principles of topicworthiness: different values of animacy, agency, definiteness, and so on (Aš nuoširdžiai dèkoju Jums / esu nuoširdžiai dèkingas už pagalba (I thank you with all my heart / I sincerely thank you for your help); Aš tariu Jums nuoširdžiq padeka (I am extending my sincere thanks to you)). When it comes to topicworthiness, the indirect object of the dative (to you) ranks second after the subject nominative to become the topic of the sentence. Then, the rheme of the sentence is expressed with a non-typical subject: a noun denoting an abstract thing (Jai tenka nuoširdžiausia padèka (Sincerest thanks go to her); cf., Jums patinka klasikine muzika (You love classical music)). The keyword or modifier of gratitude can be turned into a rheme by choosing to use active resp. passive constructions ( $A$ š skiriu Jums nuoširdžia padèka (I give you my sincere gratitude) resp. Jums skirta mano nuoširdi padèka (You have my sincere gratitude)), exclamatory sentences (Dèkoju širdingai jums už svetingumą! (I sincerely thank you for your hospitality!) Kokia aš tau dekkinga! (How grateful I am to you!) Kaip dèkui, kaip ačiū! (Thanks so much!)). By using inversely worded thank-you 
constructions, the addresser accentuates the keyword of gratitude (Dékoju labai (Thank you very much)), its valence actant (Jums (o ne kam kitam) labai dékoju (Thank you (and not someone else) very much)) or modifier (Jums dèkoju (ne bet kaip, bet) nuoširdžiai (I thank you (not just in any way, but) sincerely)), much like in cases when the constructions dekoju labai (thank you very much)), dékingas esu labai (I am very grateful), and so on. If the word order is neutral, the contrasting rheme is evidenced by the word tai (so) (Tai labai, labai dekui (So thanks a lot)).

The limited number of LINGUEE translations have failed to confirm any influence an unmarked word order in the English or German language may have on the marked usage of dekui labai (thank you very much) in the Lithuanian language.

Considering the actual usage of the modern Lithuanian language and the different strategies of expression of gratitude chosen to (non-)actualise the state resp. act of gratitude (esu labai dékingas (I am very grateful) resp. labai dèkoju (thank you very much) resp. labai dèkui (many thanks)), the CMLL cases have revealed that the addresser uses didelis / nuoširdus dèkui (ačiū) (many/sincere thanks) to actualise gratitude perceived as a thing (cf. Dèkui nešk Vaitiekui (Give my thanks to Vaitiekus)). In an (in)transitive sentence, the economy-sized interjection ačiū, dèkui (thank you, thanks) that is trying to wiggle its way to replace a predicate argument expressed as a noun is marked after the example of the noun padeka (gratitude) with an agreement modifier: the adjectival modifier with ači $\bar{u}$, dèkui is agreed by choosing an adjective of an unmarked gender (masculine) (nuoširdi / didelè padèka (sincere/big gratitude) resp. nuoširdus / didelis dèkui (sincere/big thanks)). In some contexts, the construction didelis / nuoširdus dèkui (big/sincere thanks) can be contrasted with labai / nuoširdžiai dèkoju (thank you very much/sincerely). Still, one should believe that in cases when, owing to the economy of language, differences in the actualisation of the expression of gratitude, and/or other reasons, ači $\bar{u}$, dèkui in a sentence takes the position of the performative dekoju or predicatively used dekingas, $-a$, interjection modifiers are chosen on the basis of the latter (labai / nuoširdžiai dèkoju (thank you very much/sincerely), labai / nuoširdžiai dèkingas (I am very/sincerely grateful) resp. labai / nuoširdžiai ačiū, dèkui (thanks a lot/sincere thanks)).

KEYWORDS: thank-you construction, interjection, inverse order of words, thematic-rhematic structure, interlanguage communication.

LORETA VAIČIULYTĖ-SEMĖNIENE்

Lietuvių kalbos institutas

Petro Vileišio g. 5, LT-10308 Vilnius

loreta.semeniene@lki.lt 